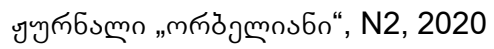

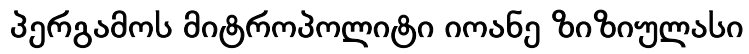

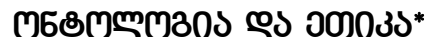

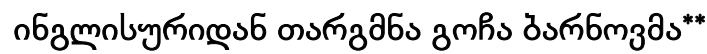

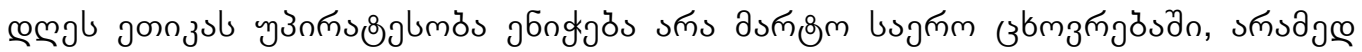

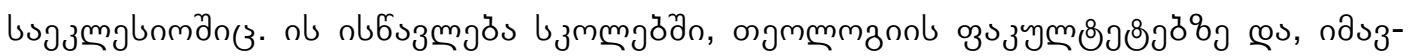

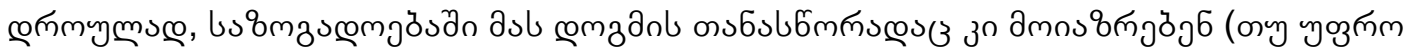

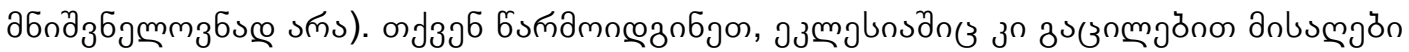

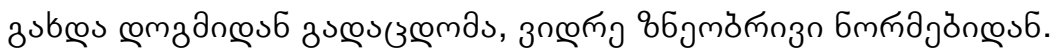

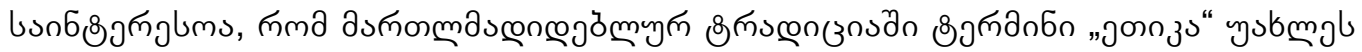

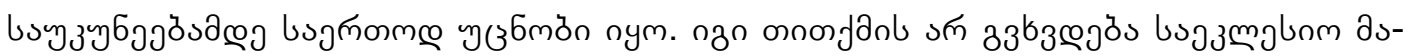

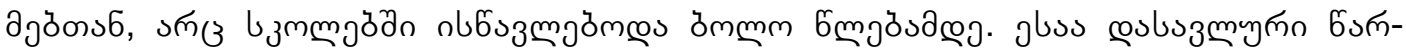

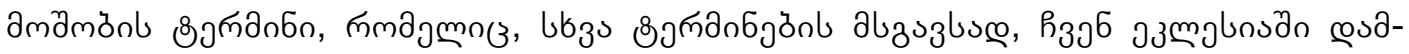

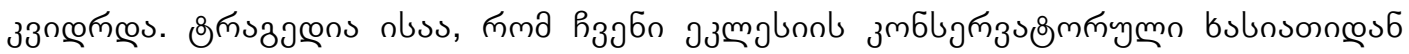

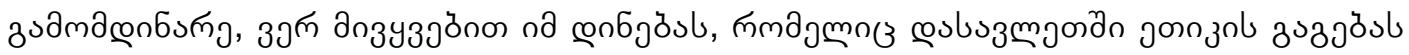

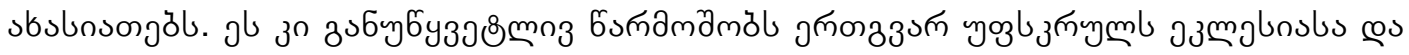

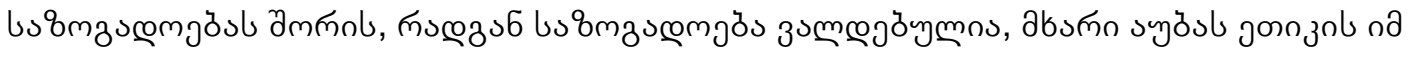

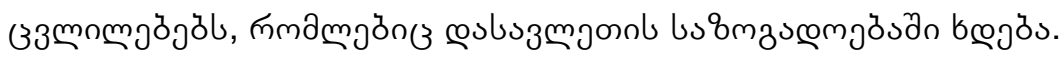

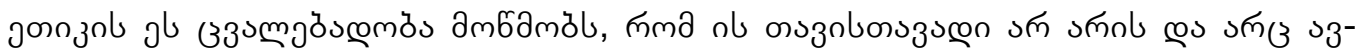

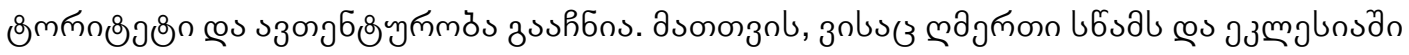

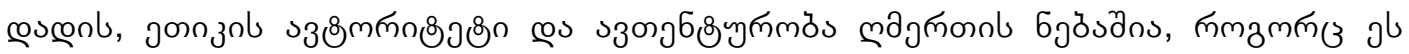

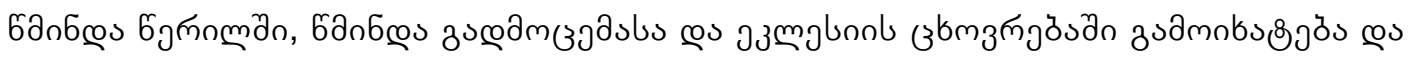

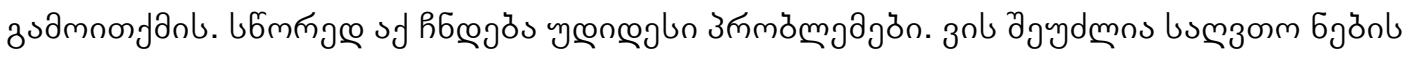

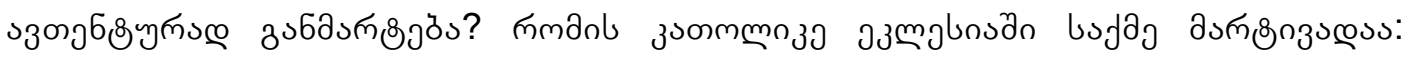

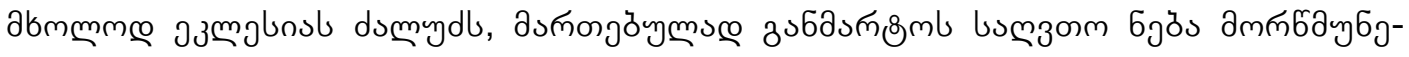

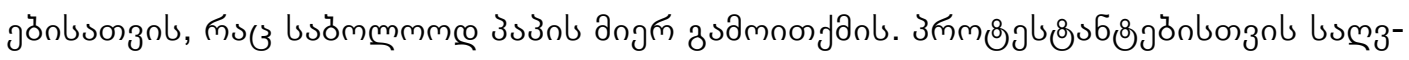

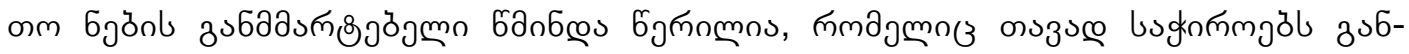

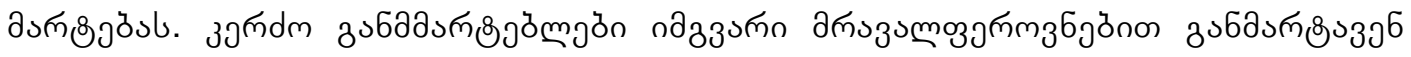

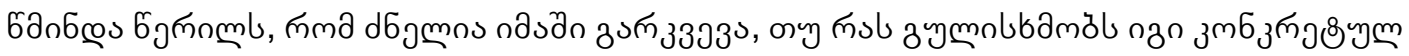

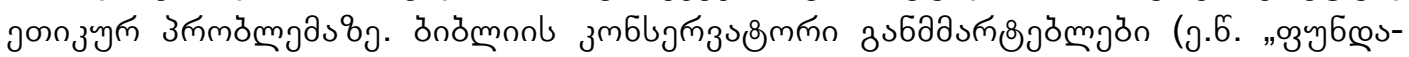

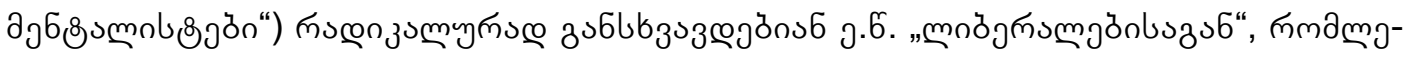

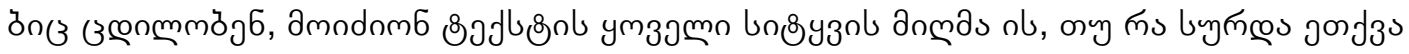

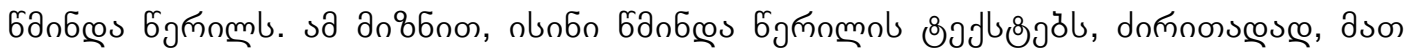

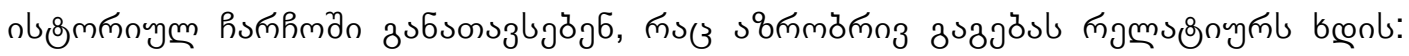

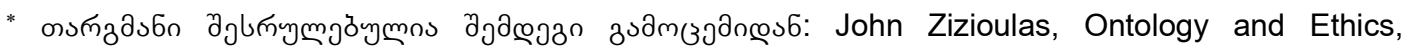
"Sabornost", No6, 2012, 1-14.

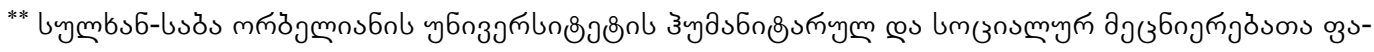

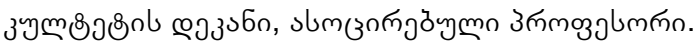




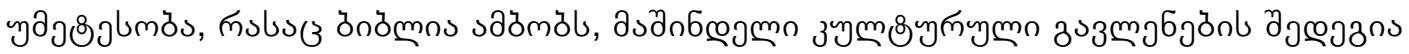

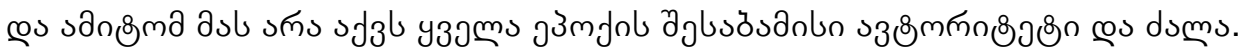

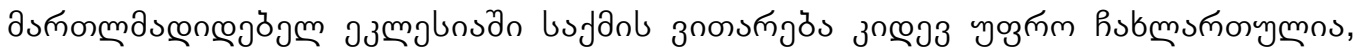

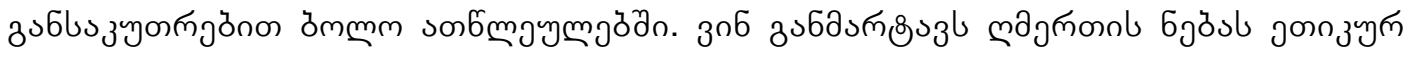

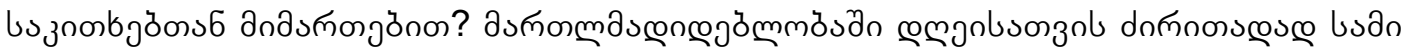

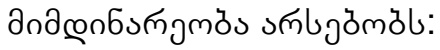

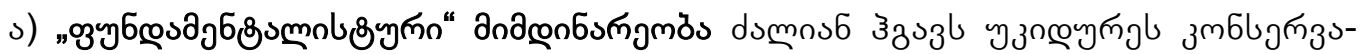

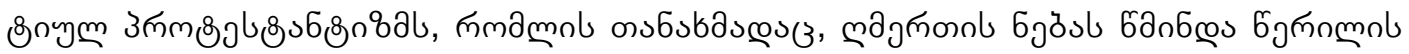

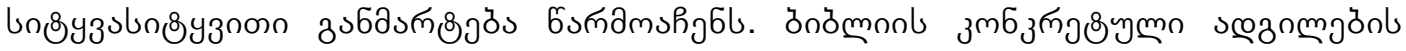

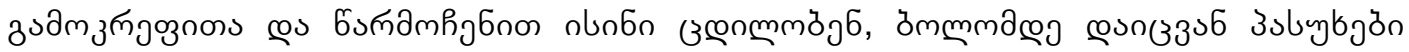

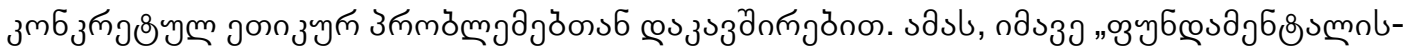

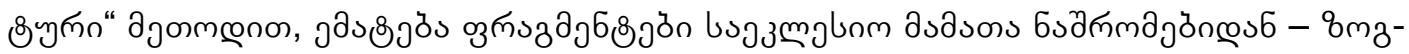

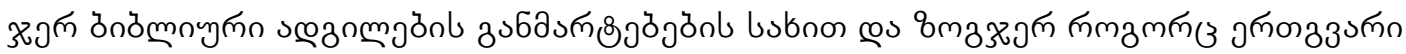

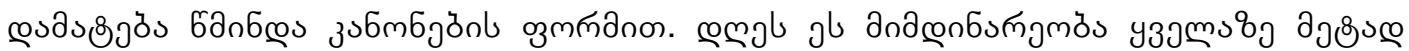

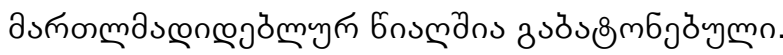

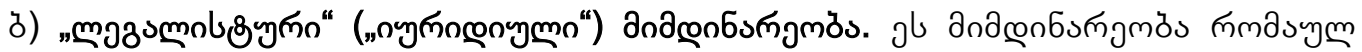

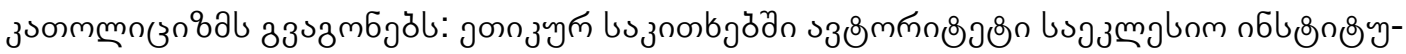

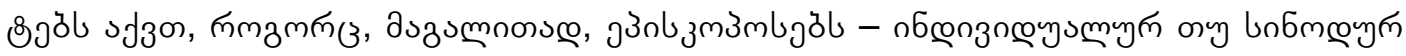

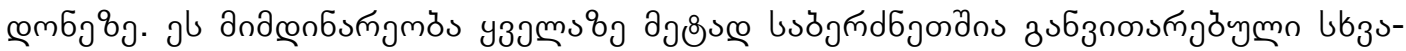

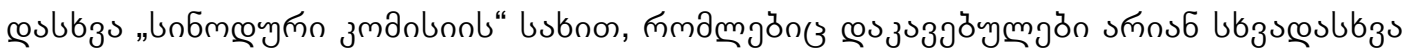

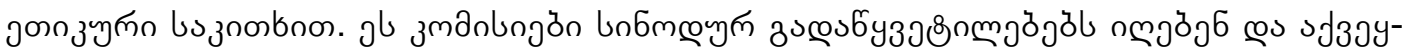

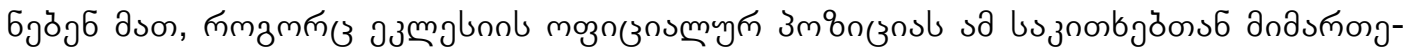

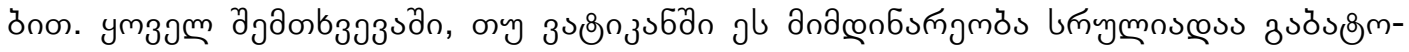
бృ

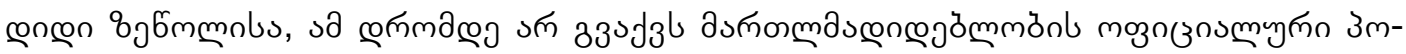

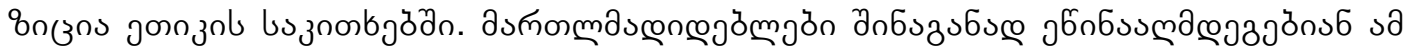

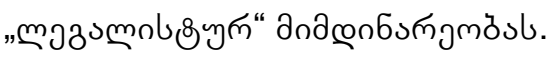

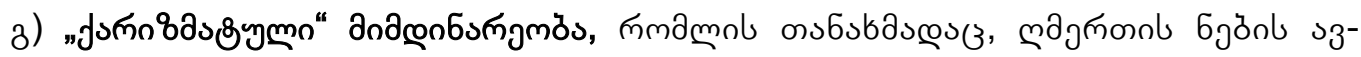

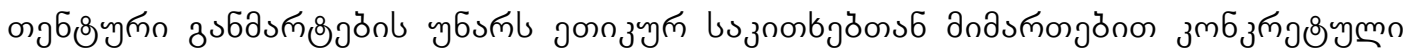

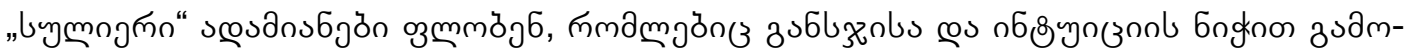

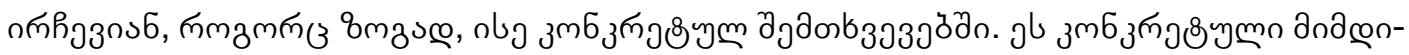

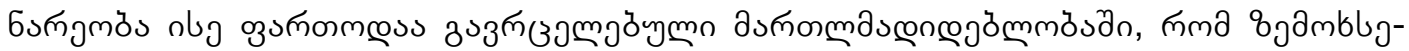

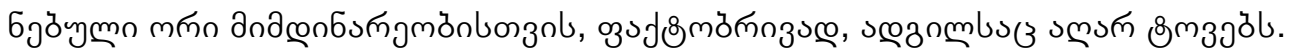

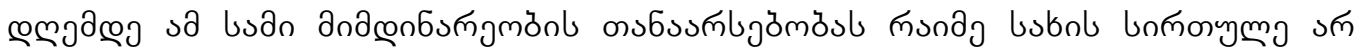

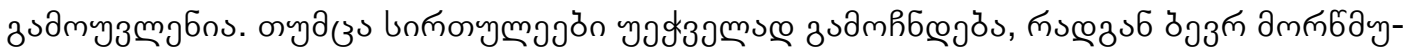

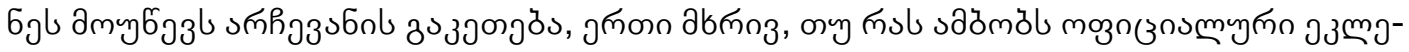

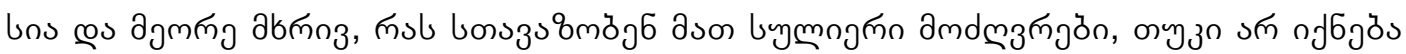

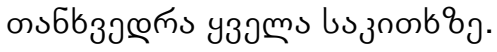

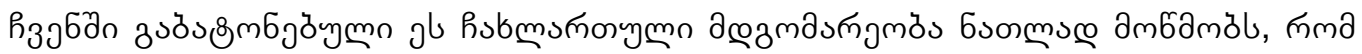

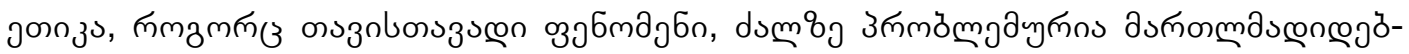

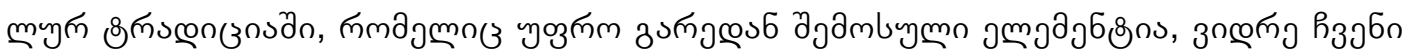




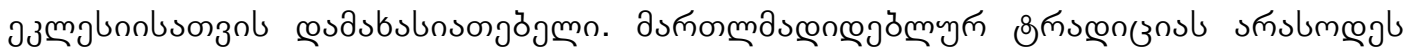

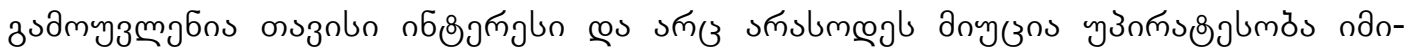

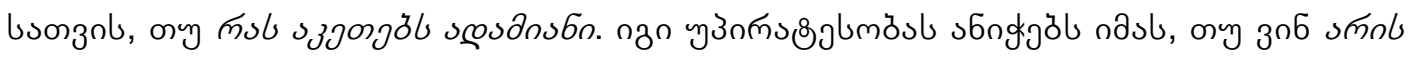

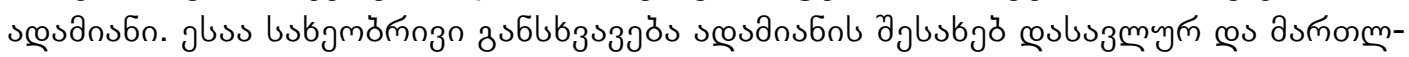

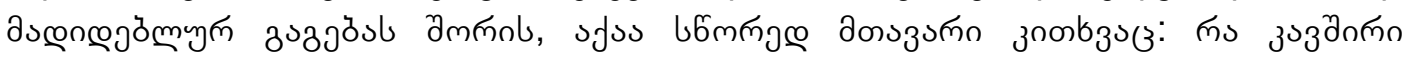

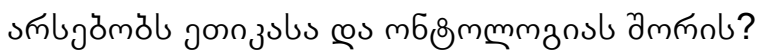

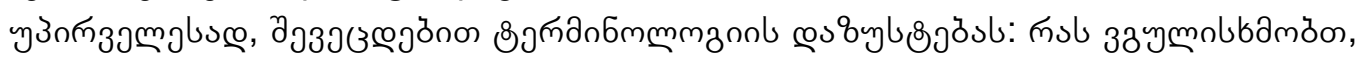
пмœ

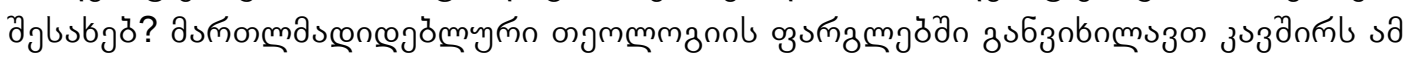

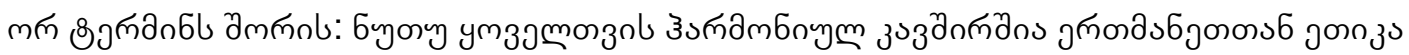

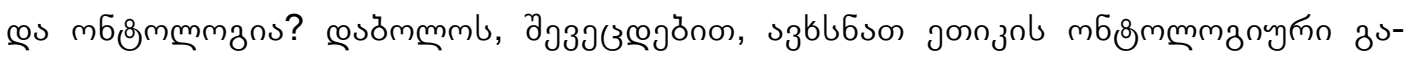

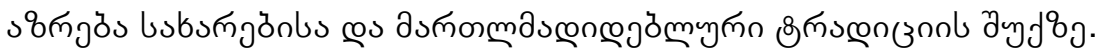

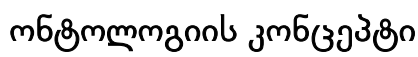

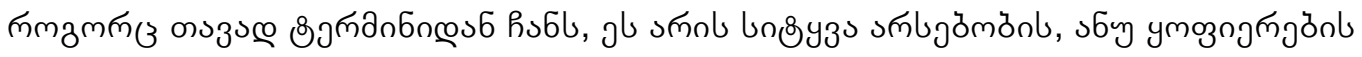
д

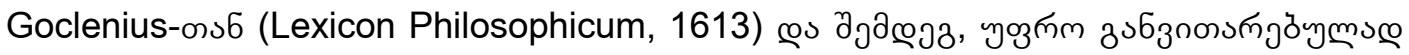

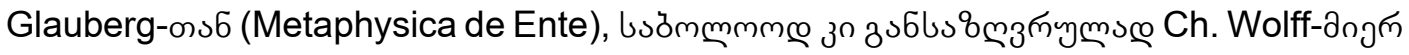

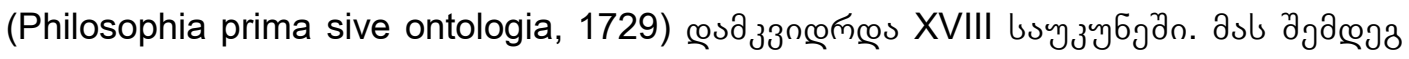

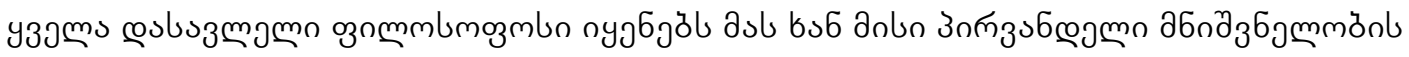

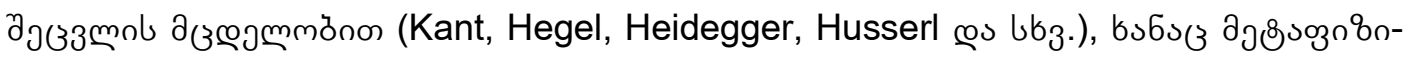

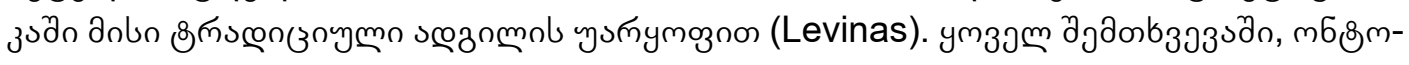

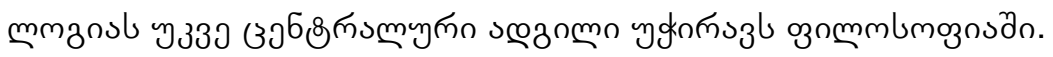

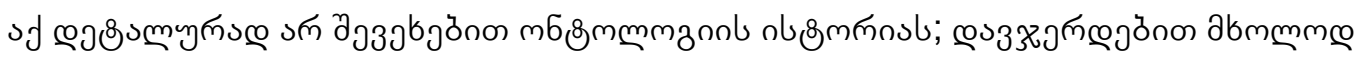

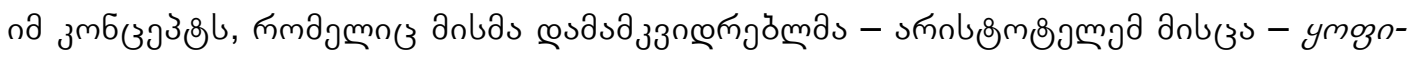

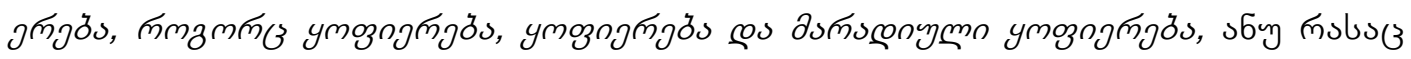

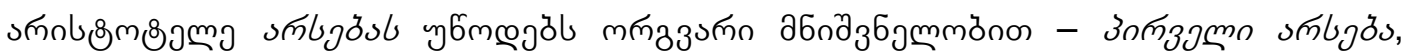

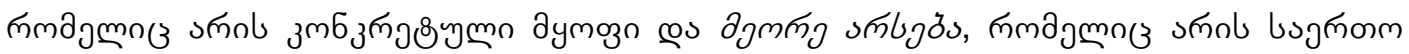

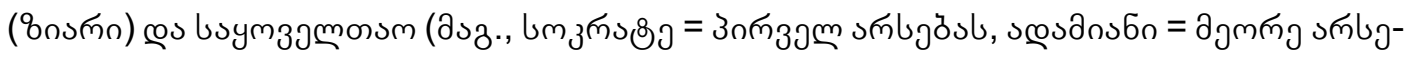
ơ).

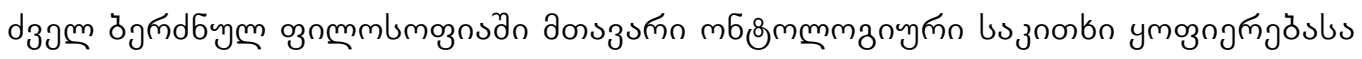

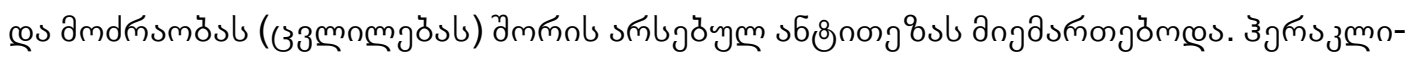

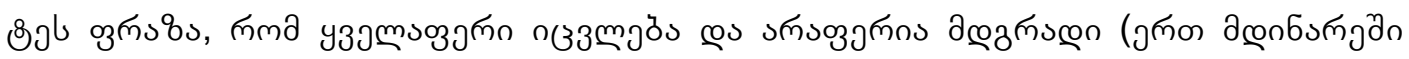

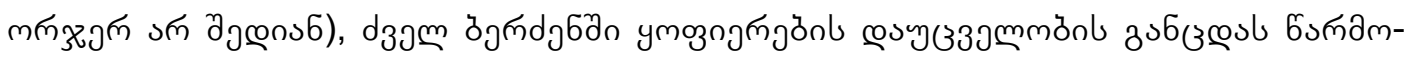

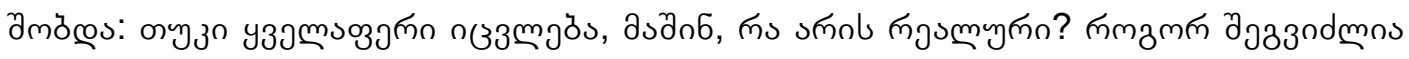

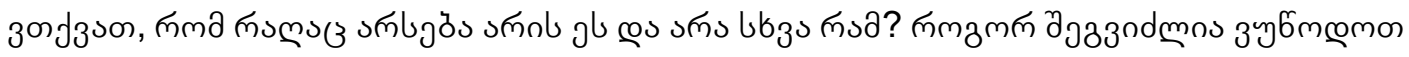

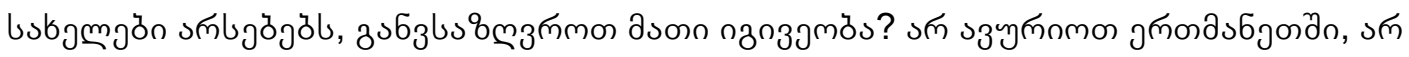

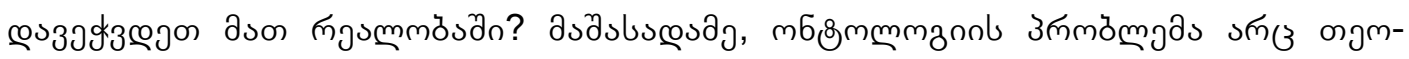

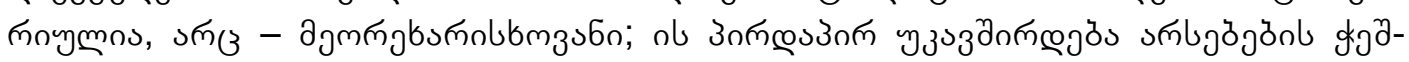

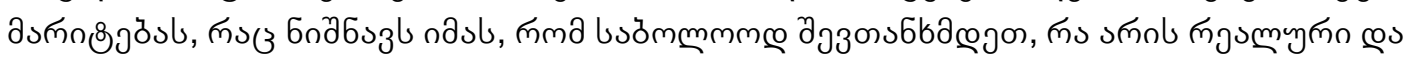




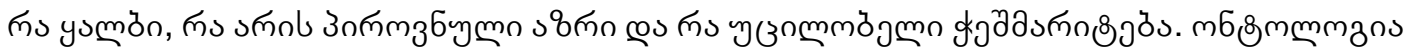

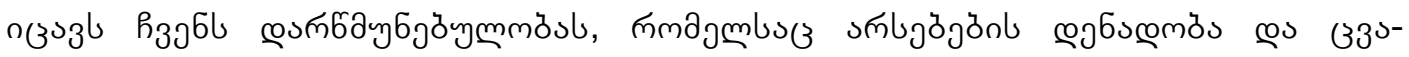

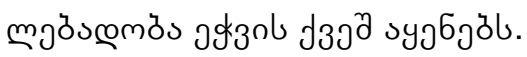

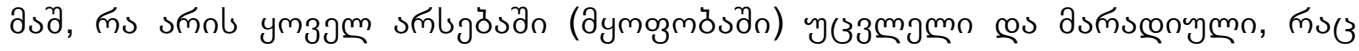

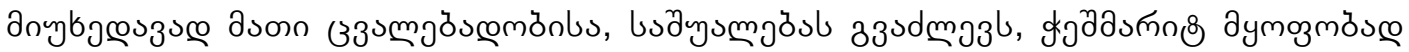

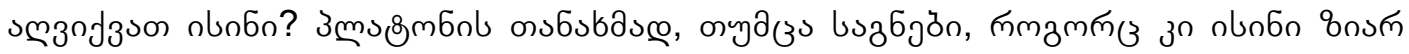

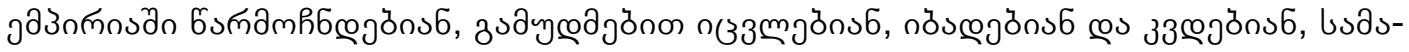

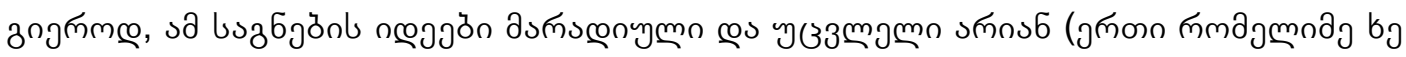

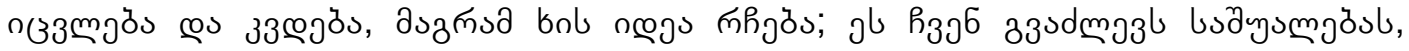

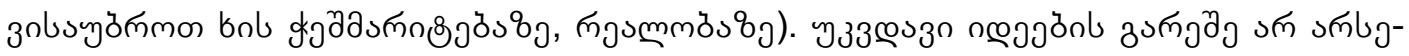

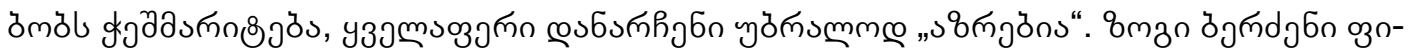

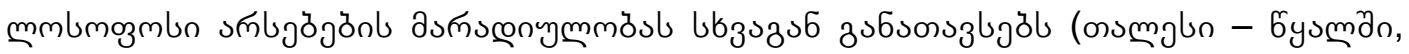

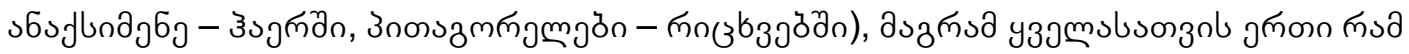

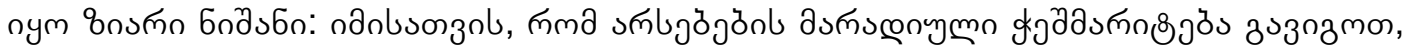

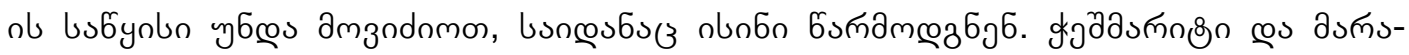

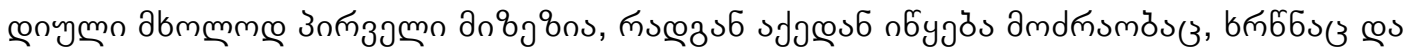

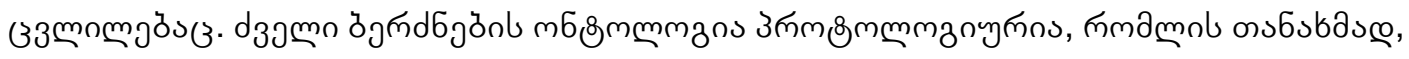

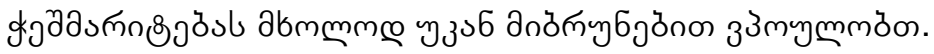

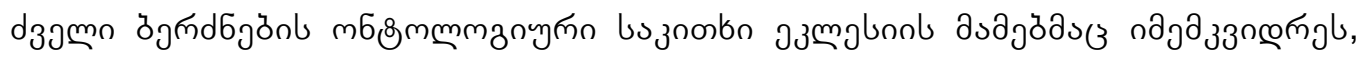

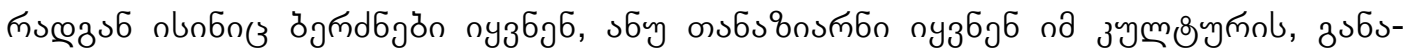

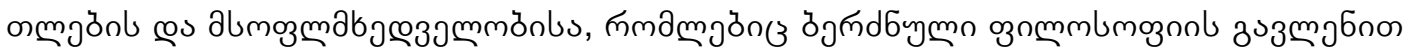

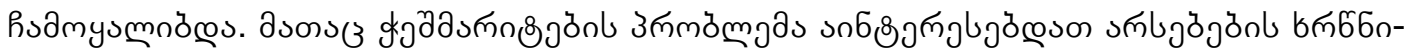

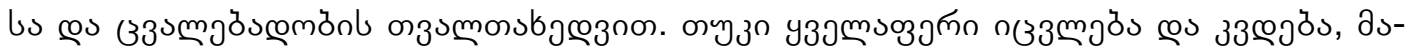

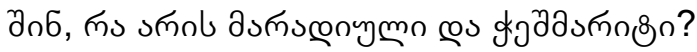

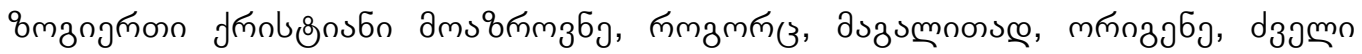

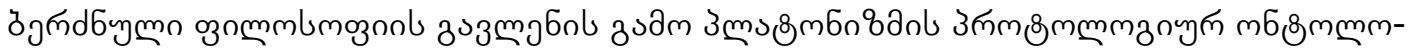

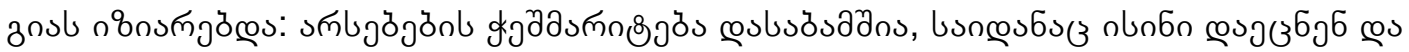

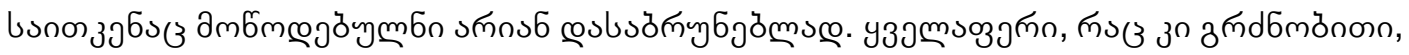

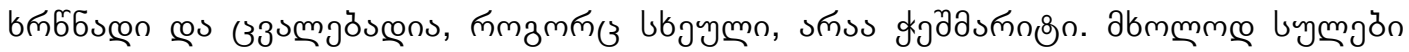

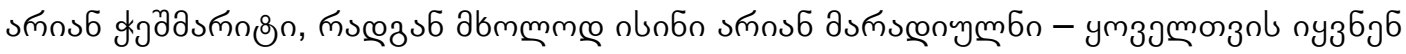
œs วyœsa n

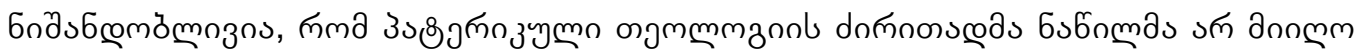

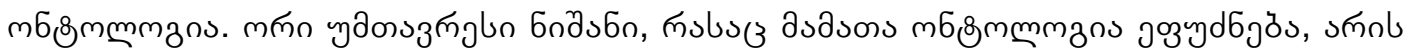
วəวœววก:

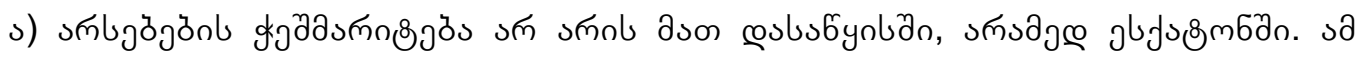

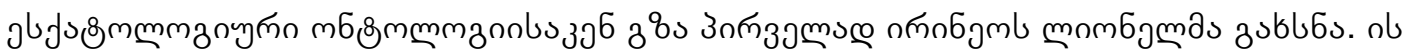

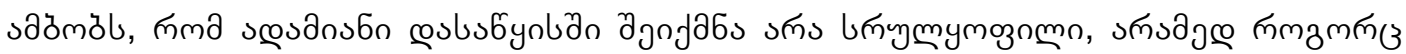

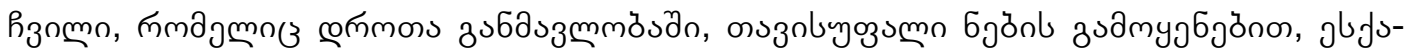

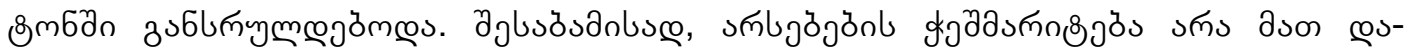

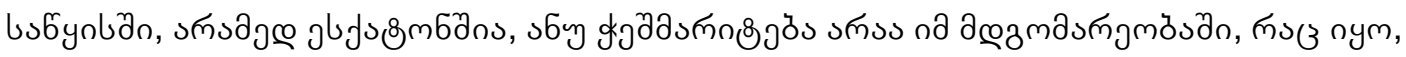

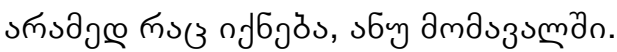




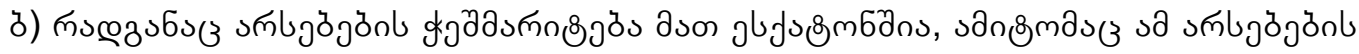

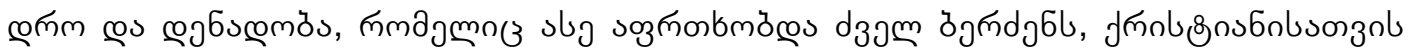

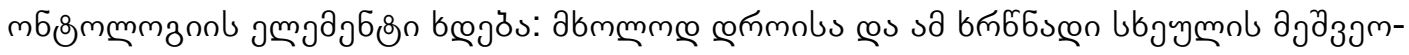

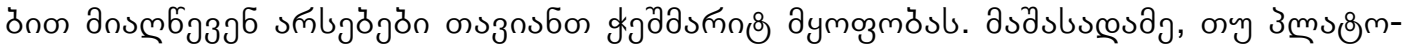

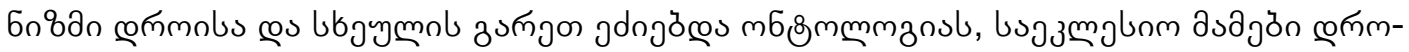

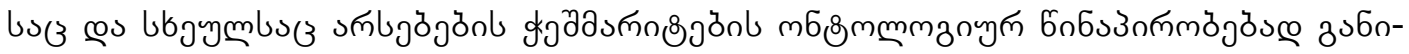

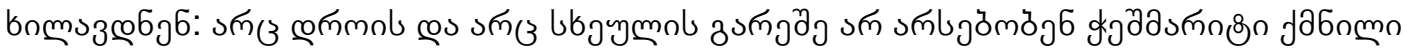

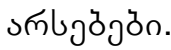

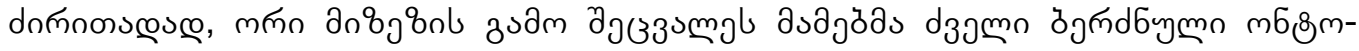

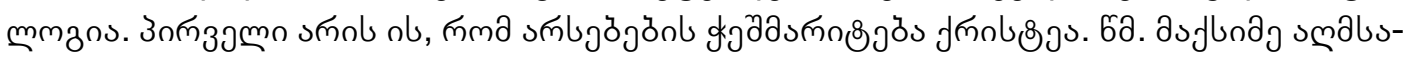

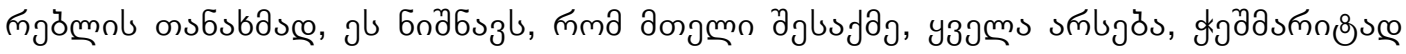

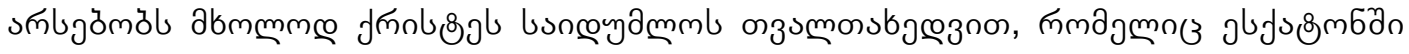

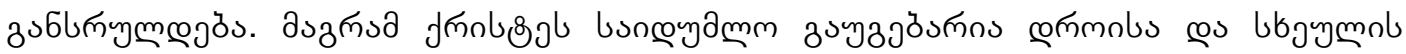

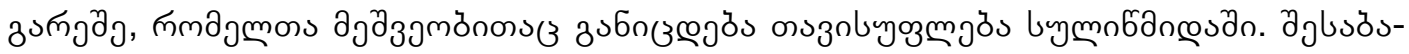

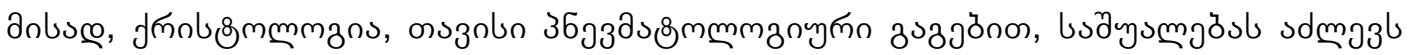
ls зmgl

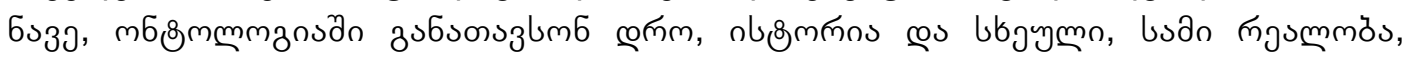

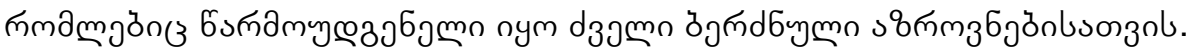

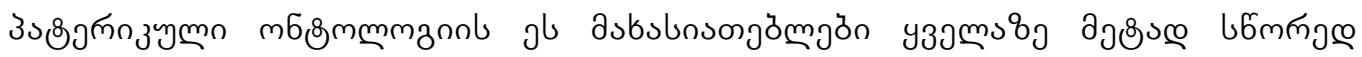

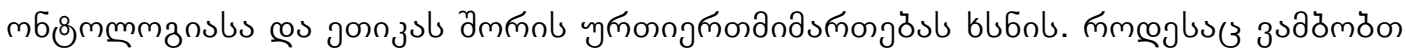

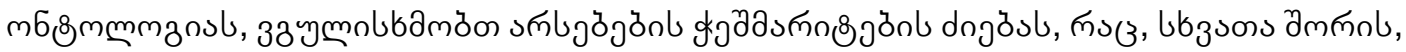

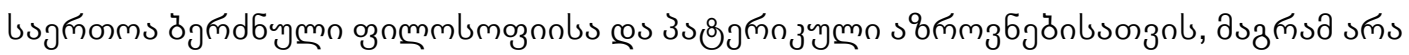

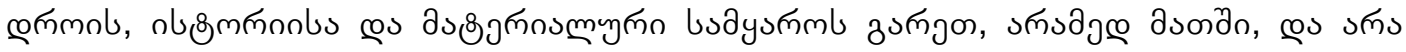

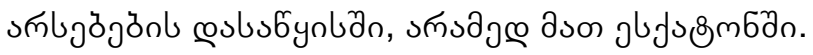

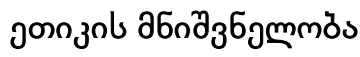

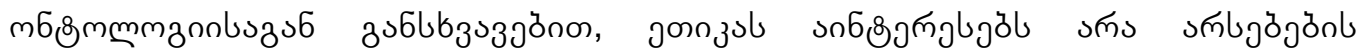

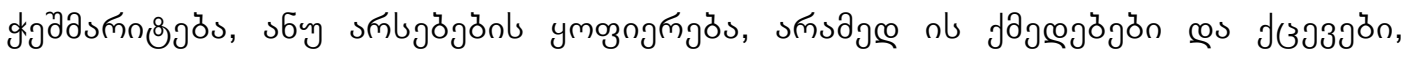

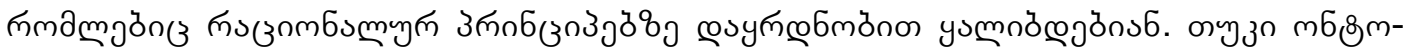

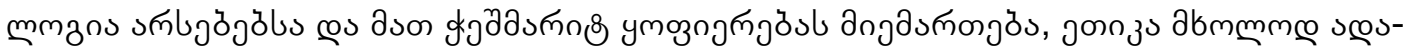

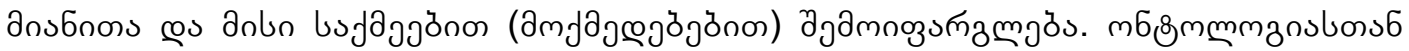
дndง

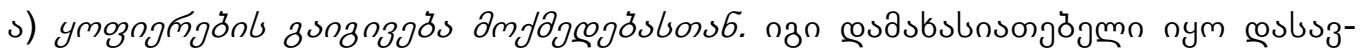

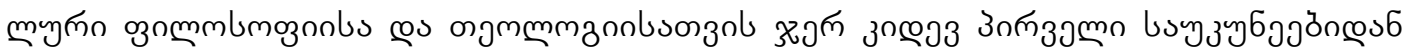
(

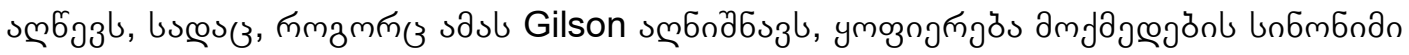

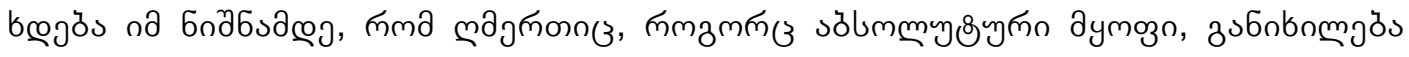

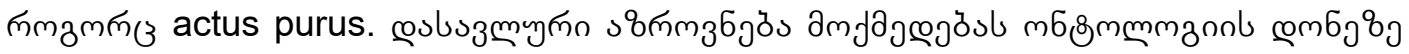

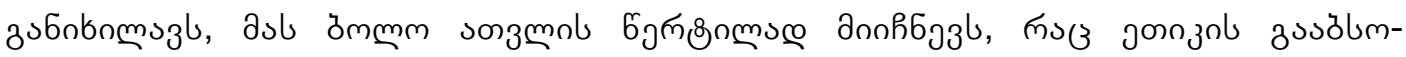

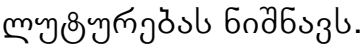




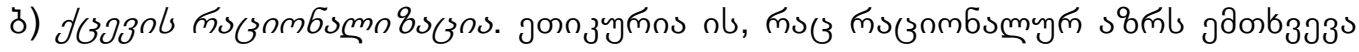
(зммовмбn).

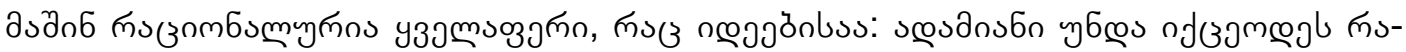

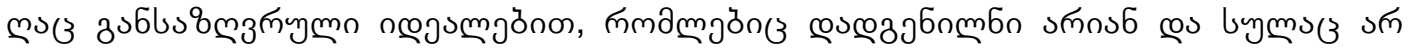

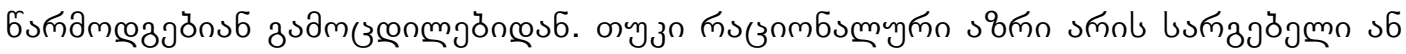

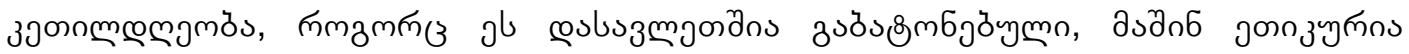

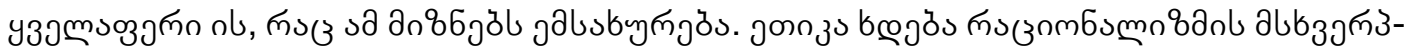

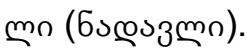

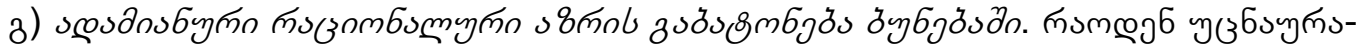

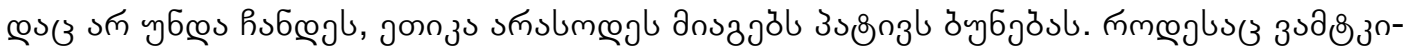

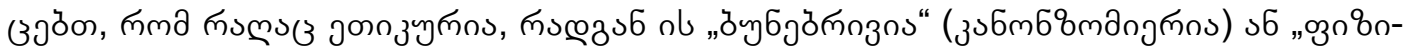

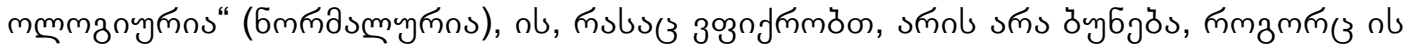

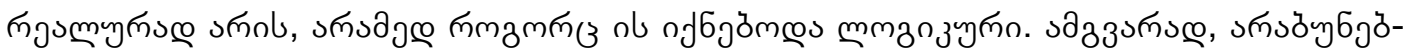

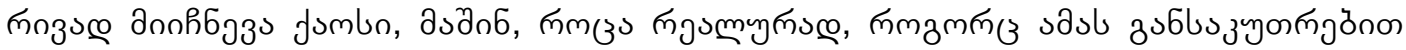

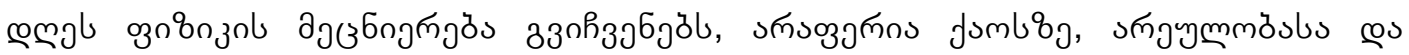

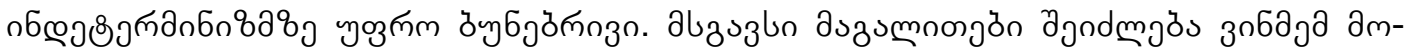
п৪)

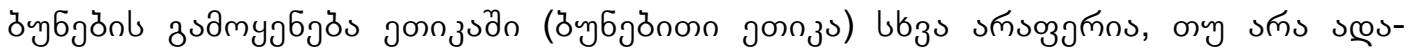

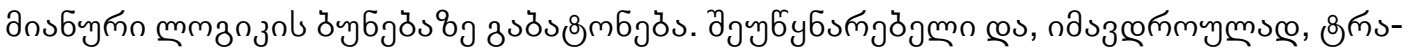

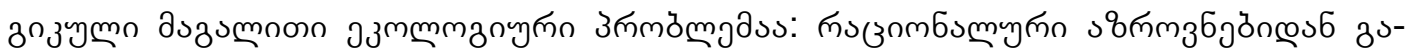

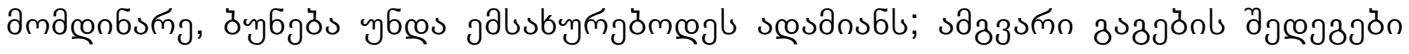

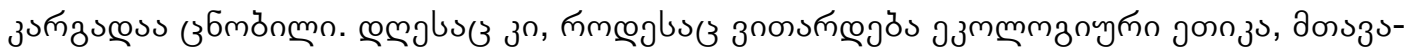

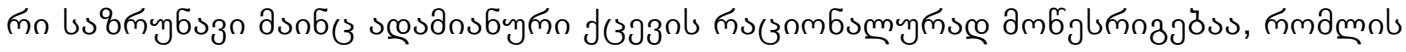

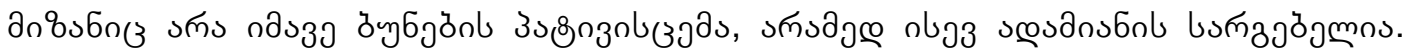

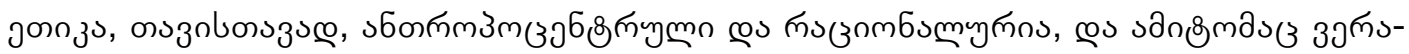
um@gl n nб

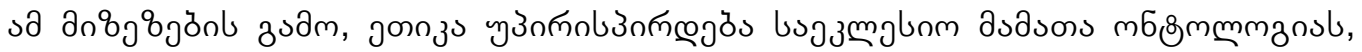

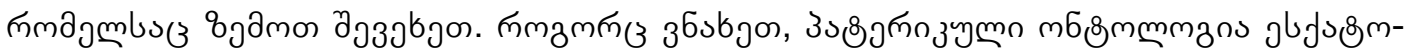

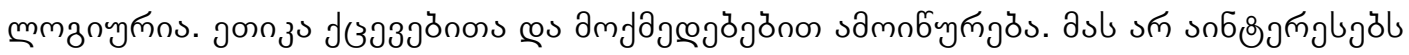

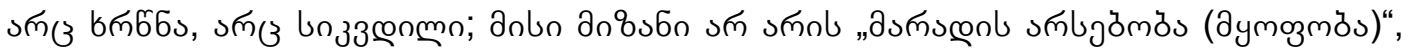

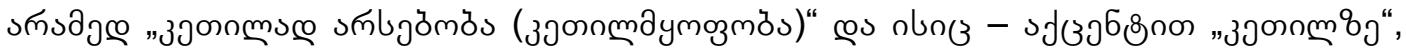

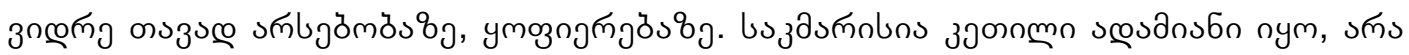

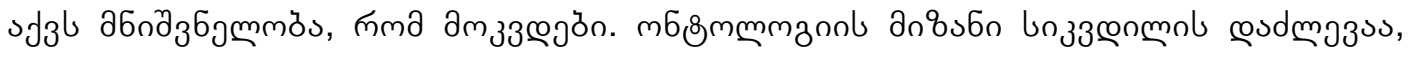

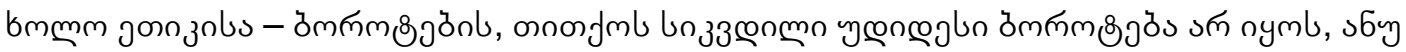

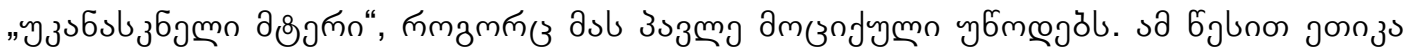

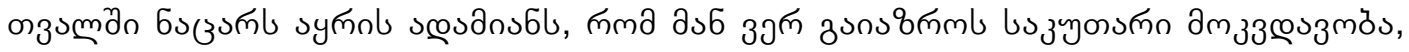

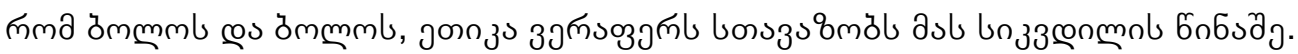

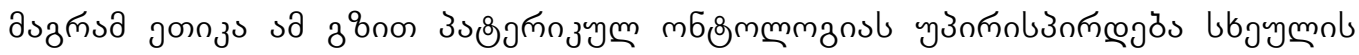

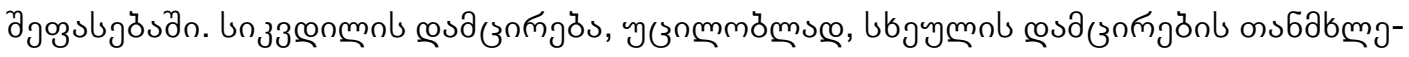

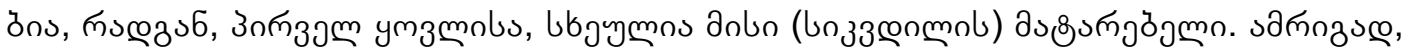

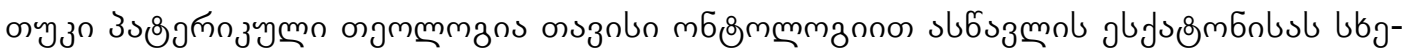




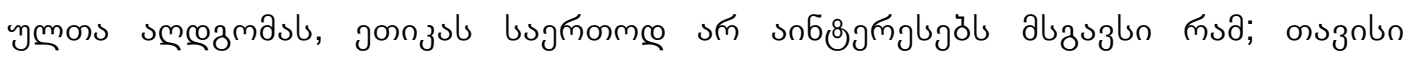

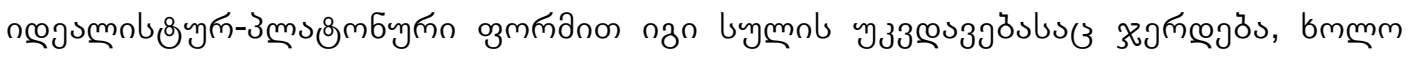

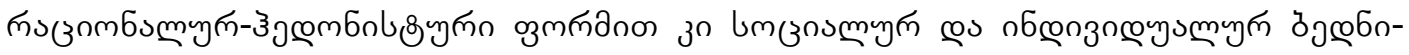

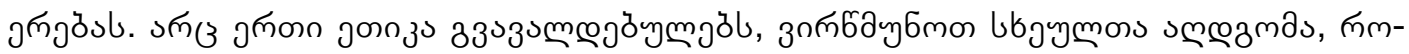

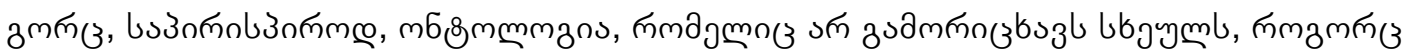
sங்

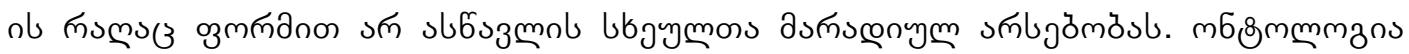

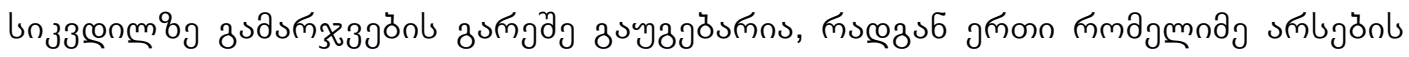

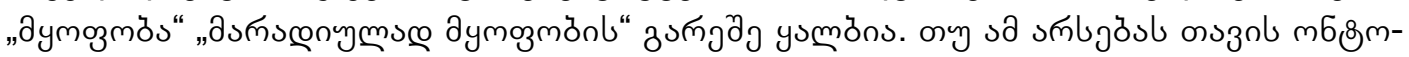

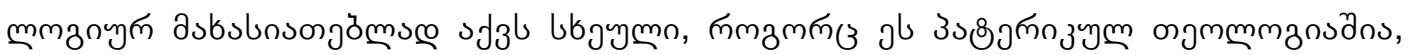

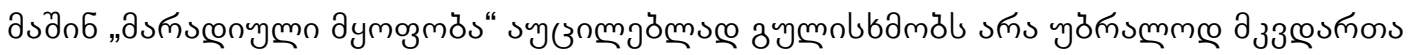

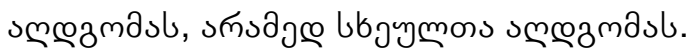

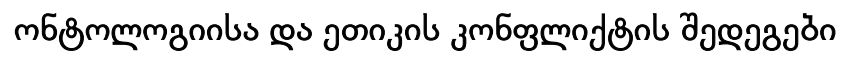

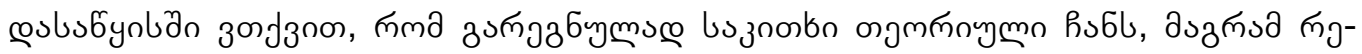

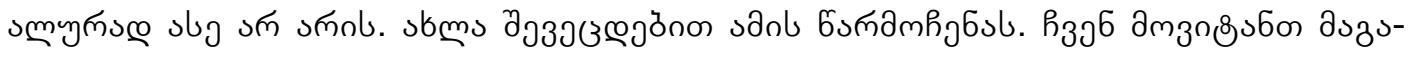

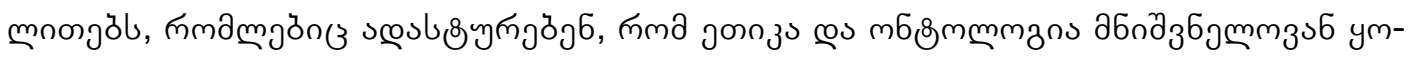

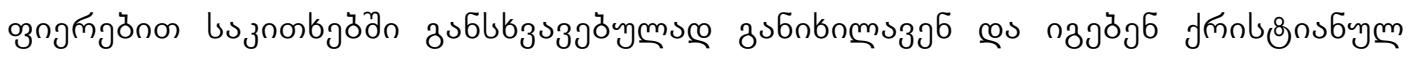
उbm3njobl.

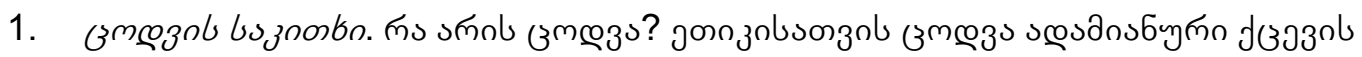

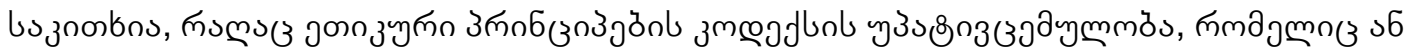

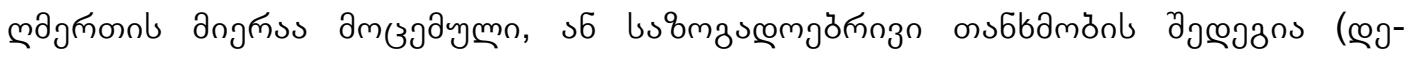

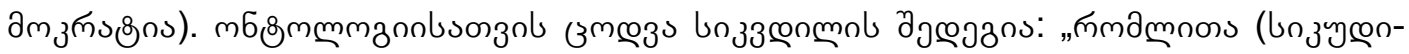

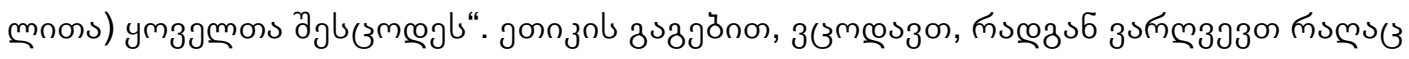

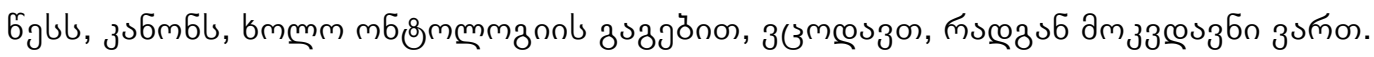

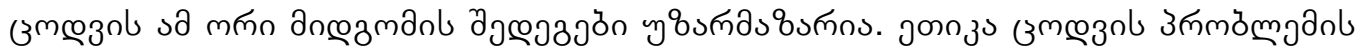

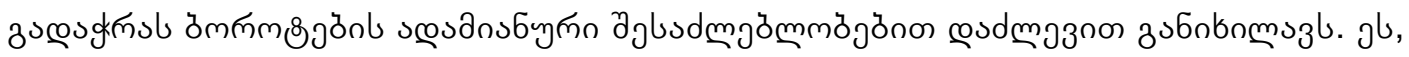

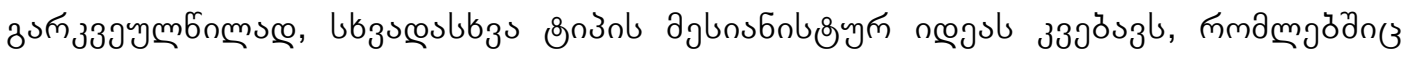

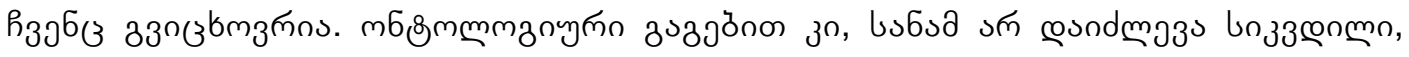

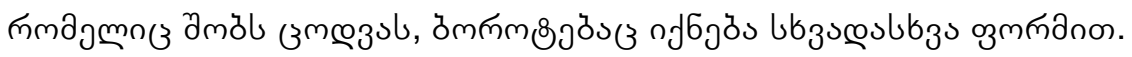

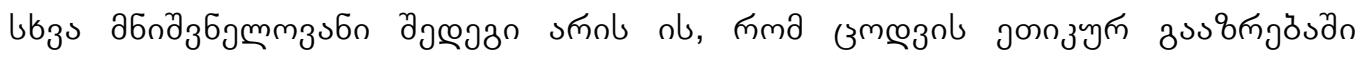

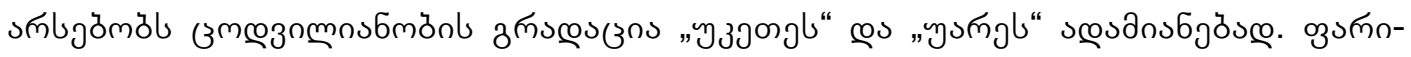

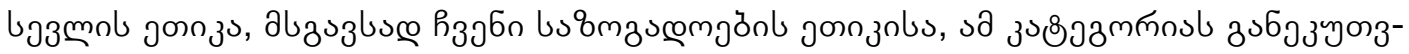

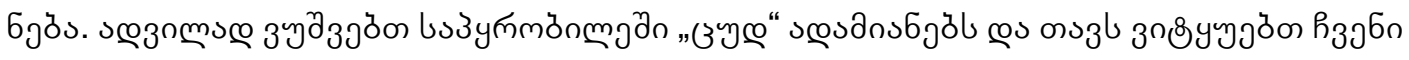

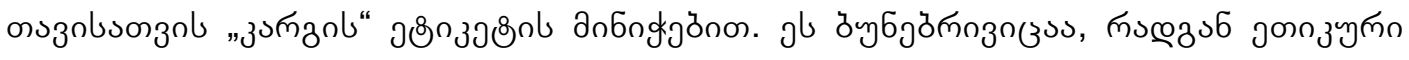

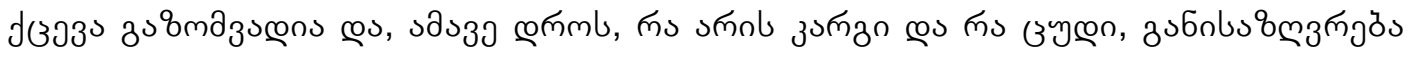

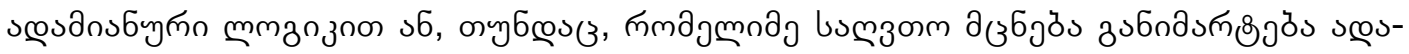

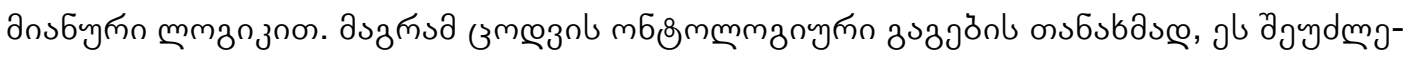

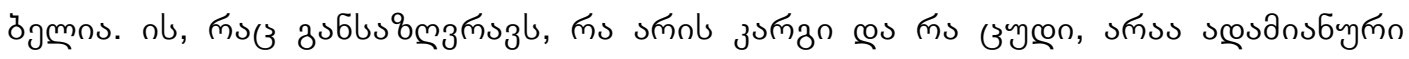




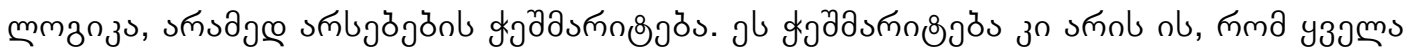

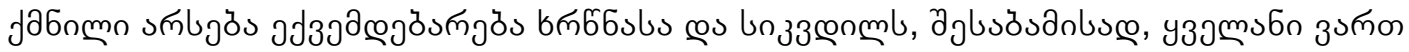

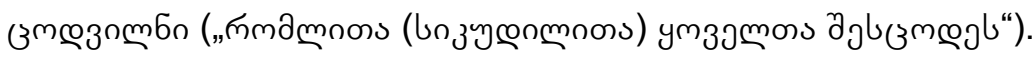

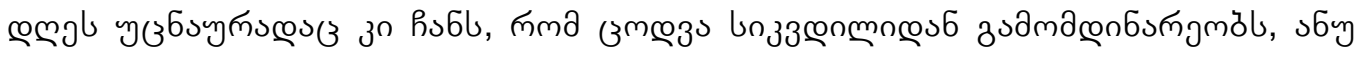

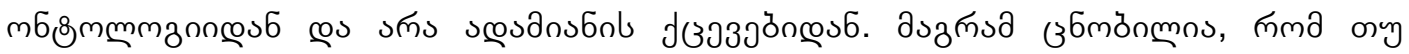

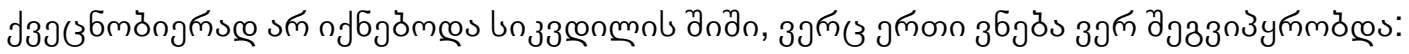

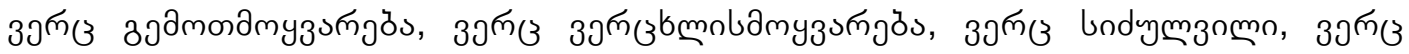

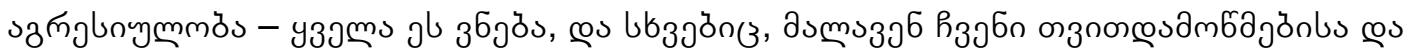

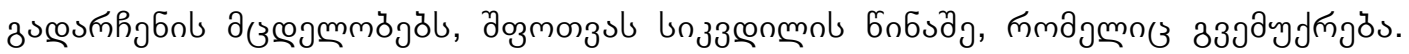

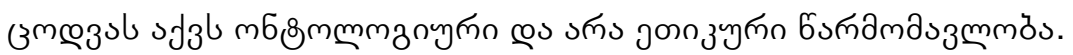

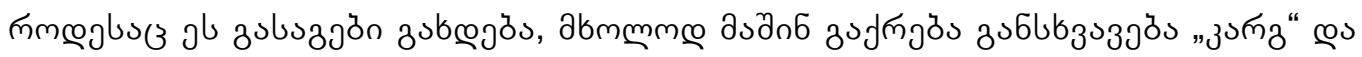

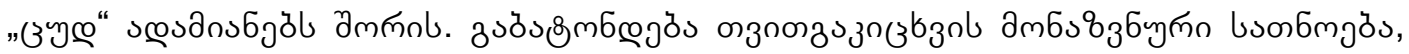

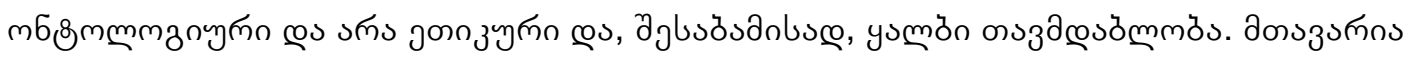

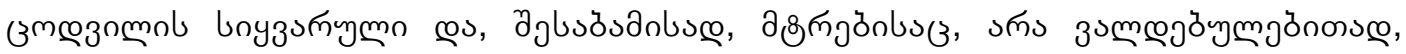

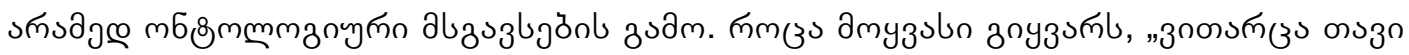

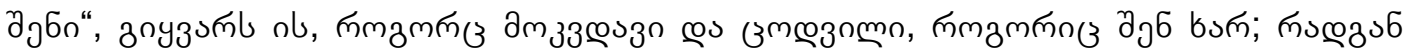

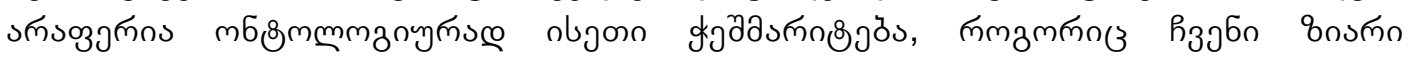

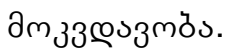

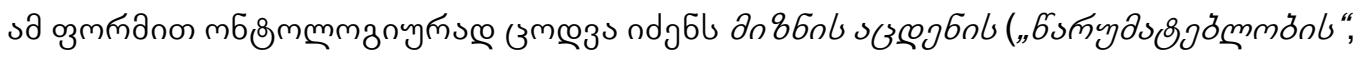

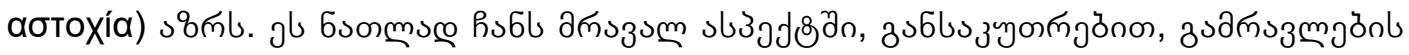

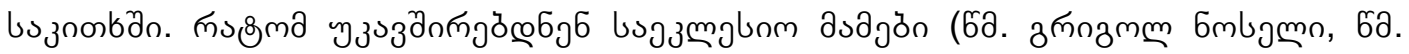

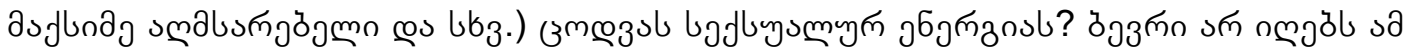

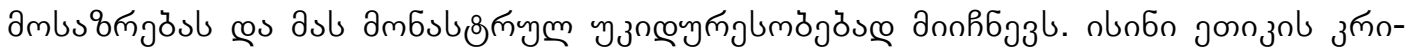

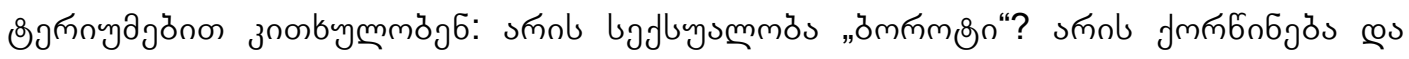

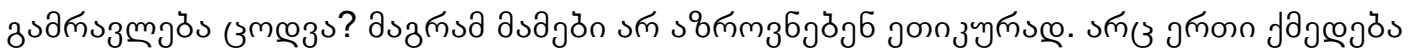

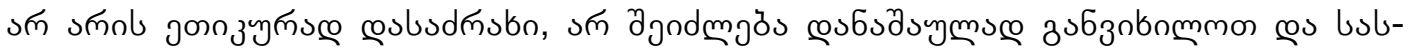

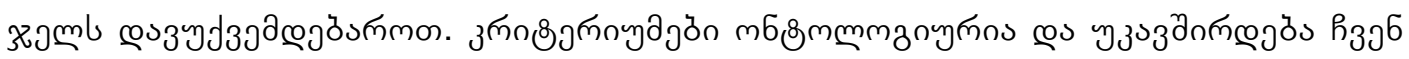

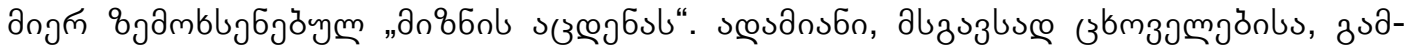

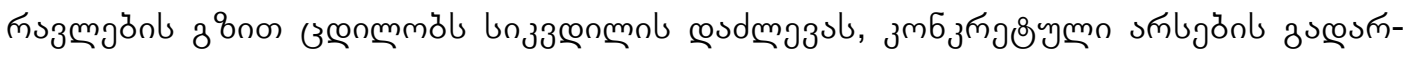

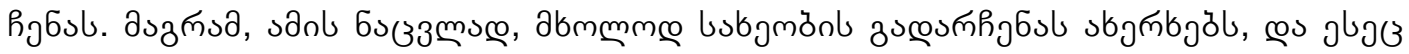

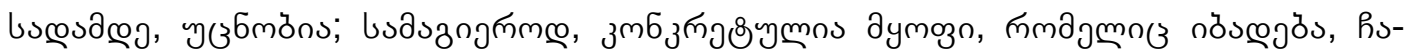

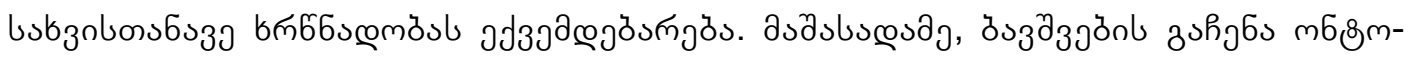

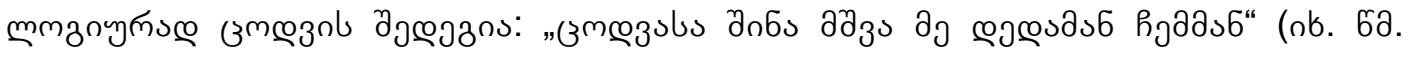

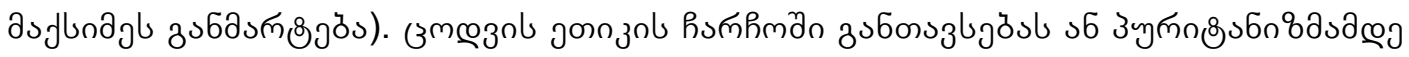

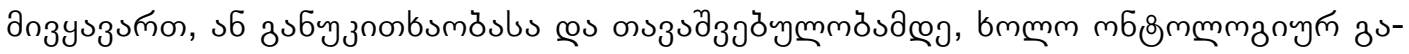
3

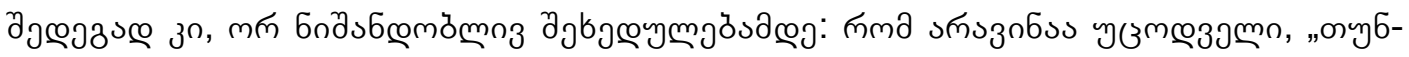

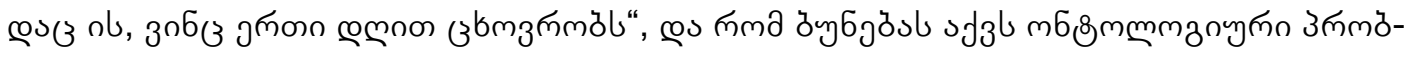

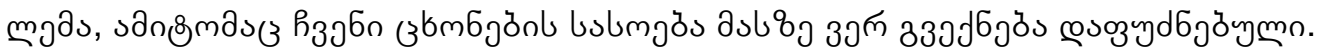




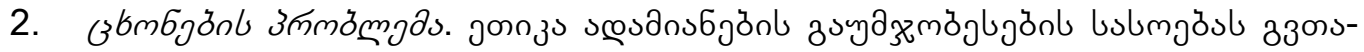
з з

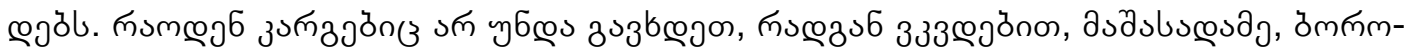
В

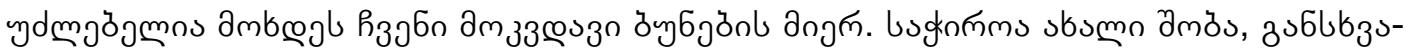

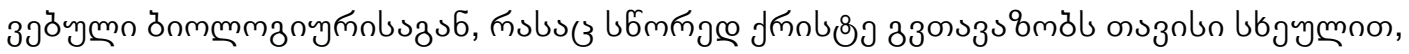
пmдjm h h ا

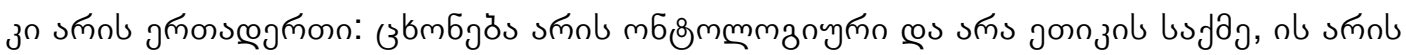

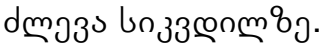

mmœg

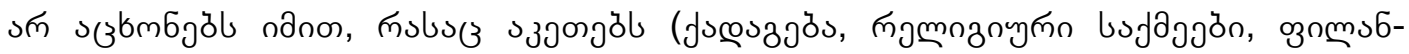

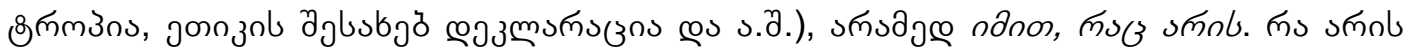

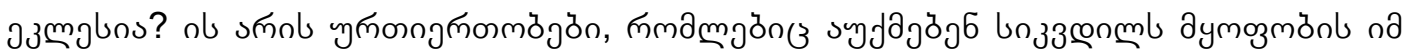

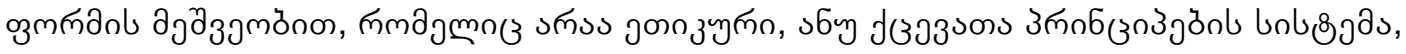

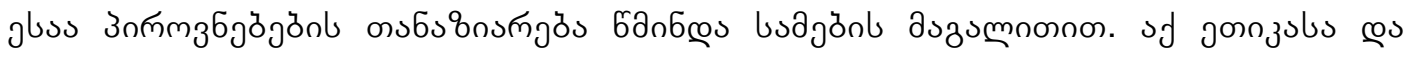

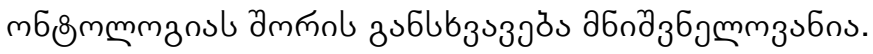

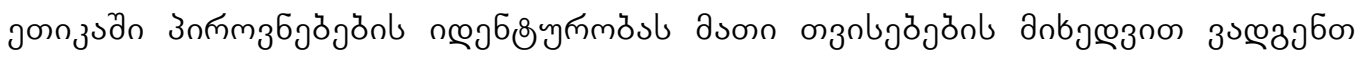

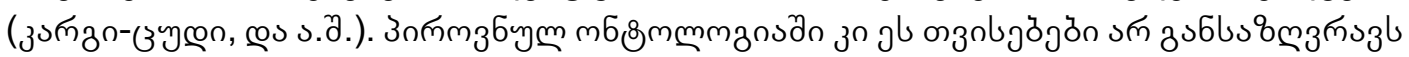

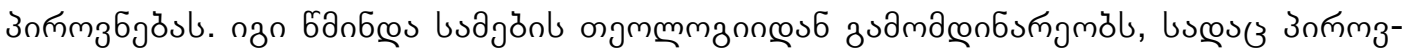

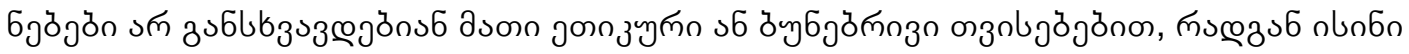

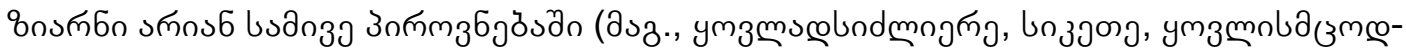

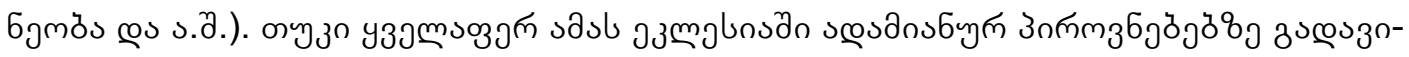

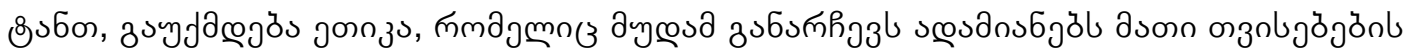

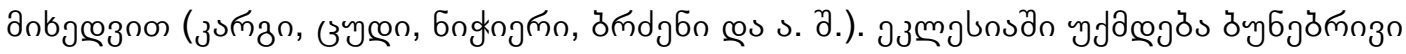

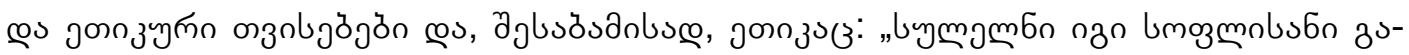

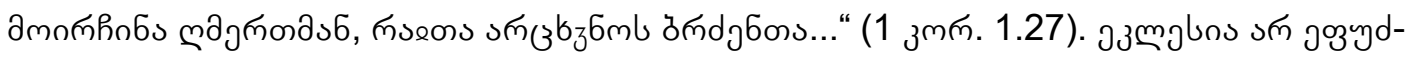

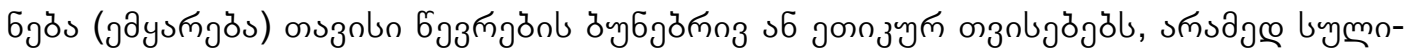

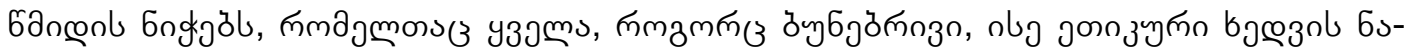
з мmзј

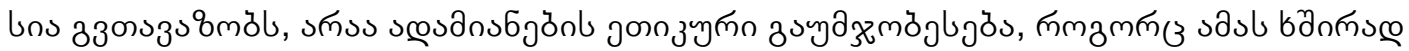

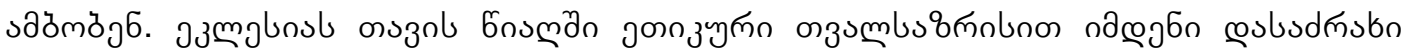
sূsans6n зузз

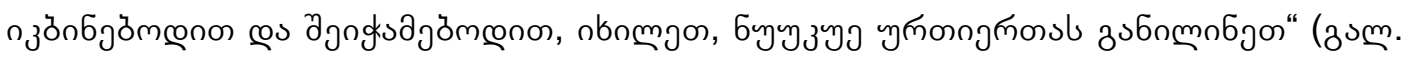
5.15).

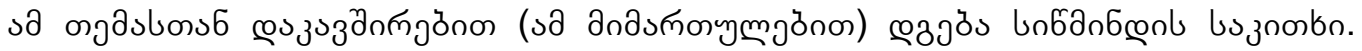

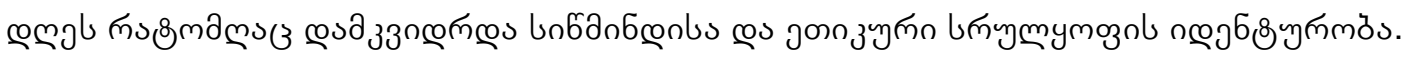

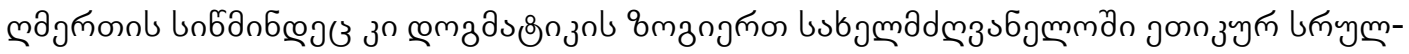

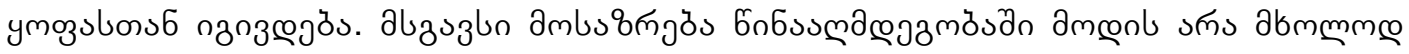

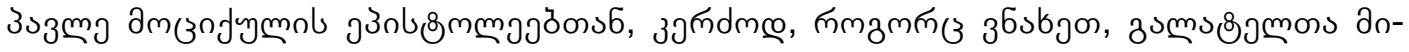




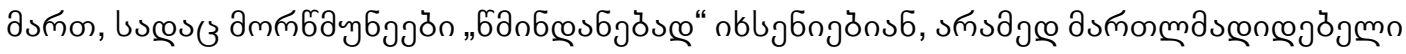

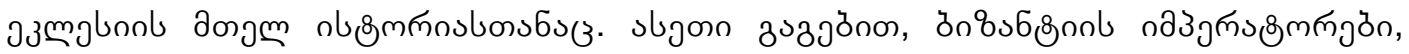

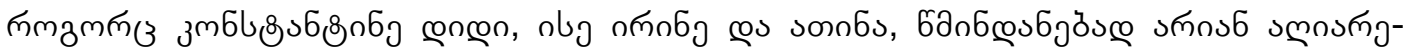

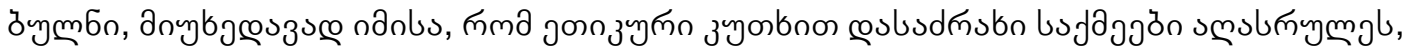

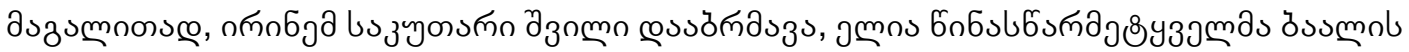

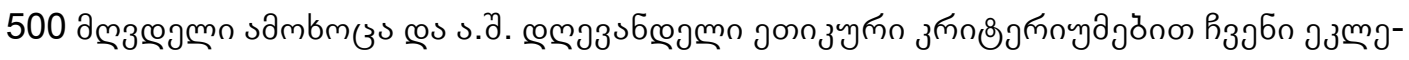

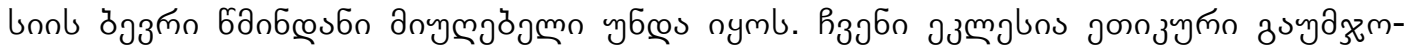

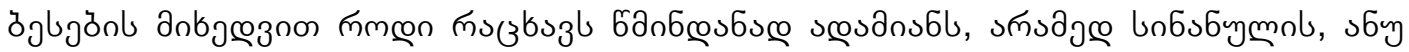

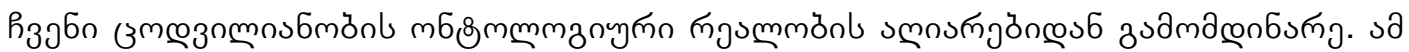

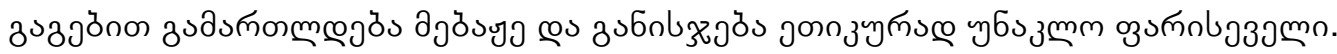

\section{m68̊mmmany̆n jonzolsonzol}

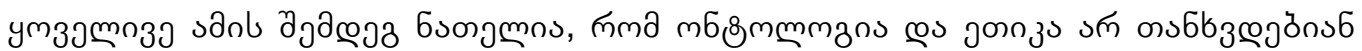

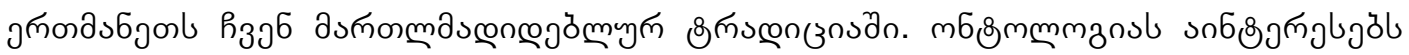

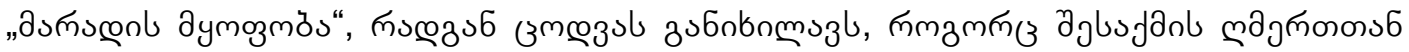

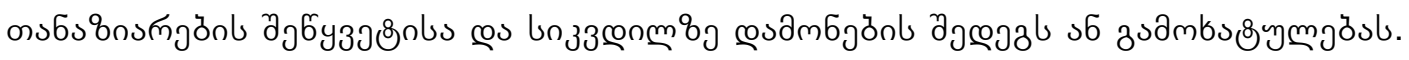

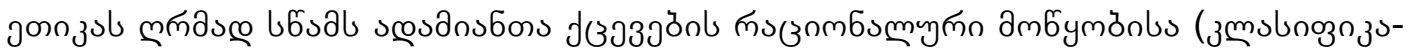

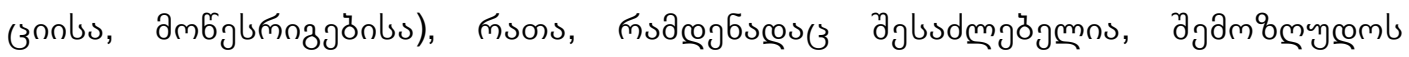

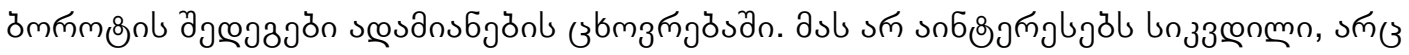

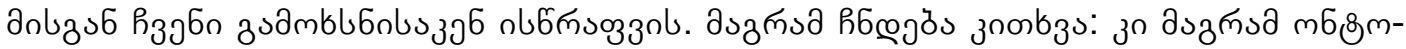

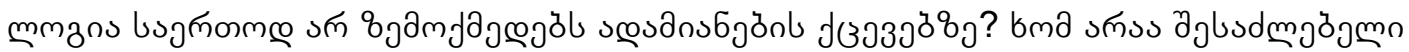

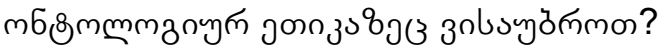

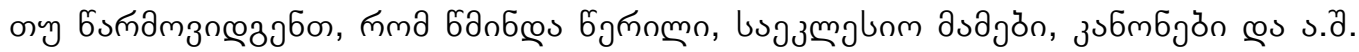

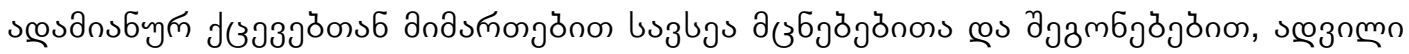

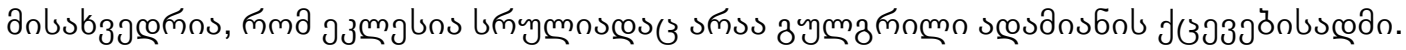

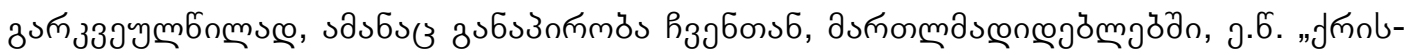

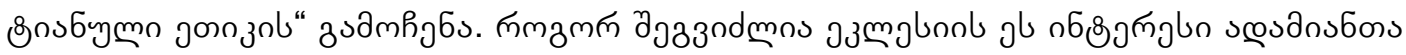

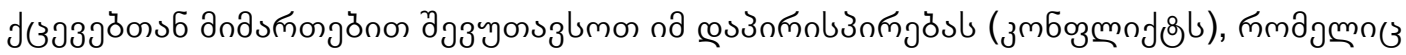

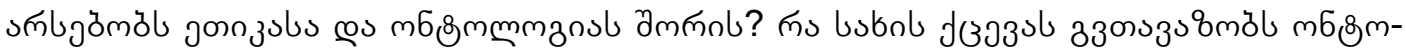

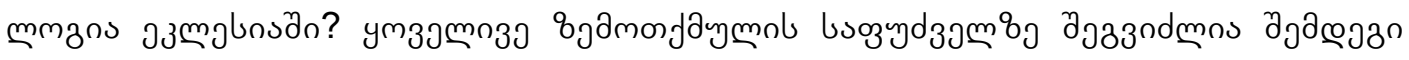

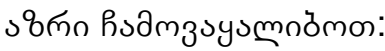

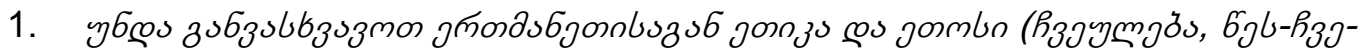

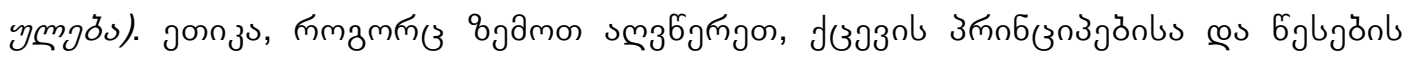

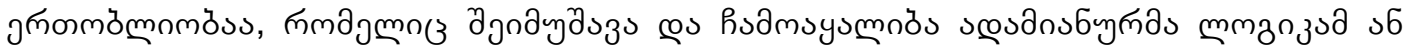

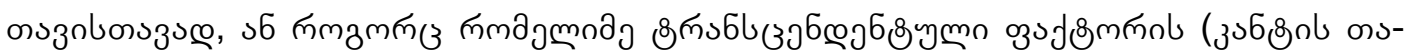

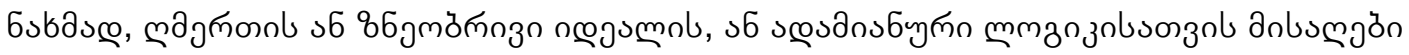

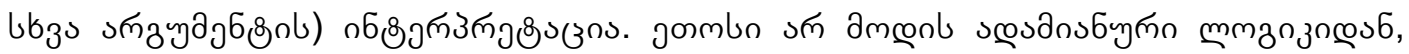

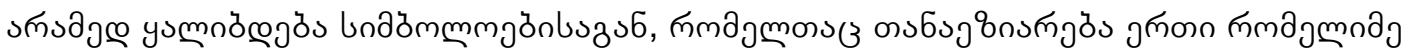

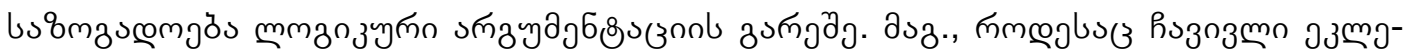




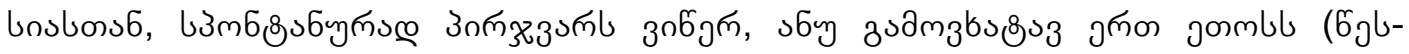

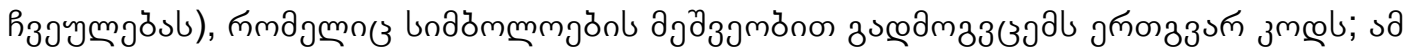

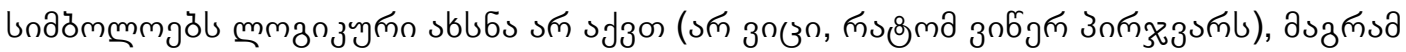

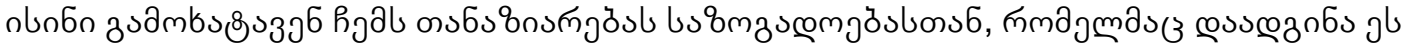

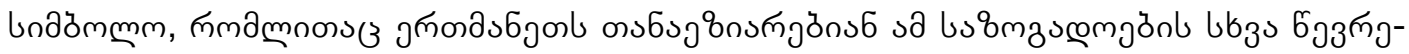

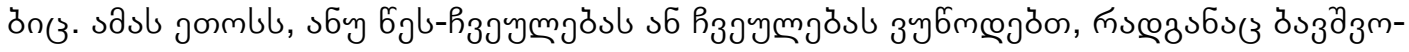

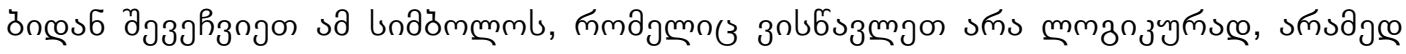

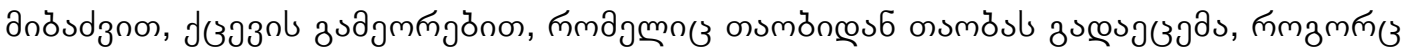

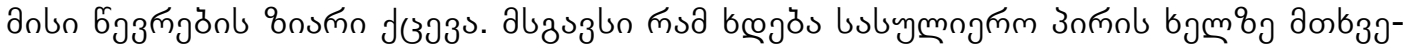

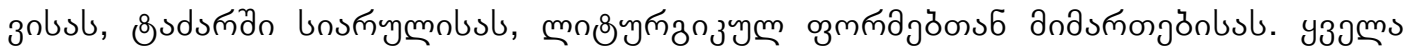

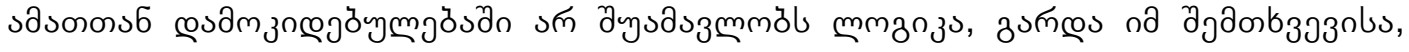

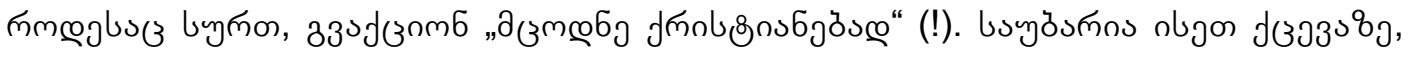

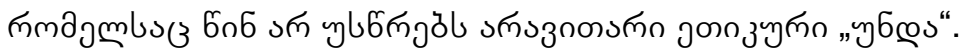

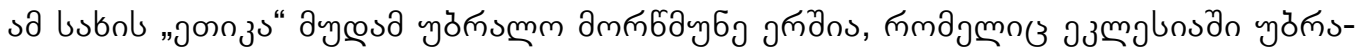

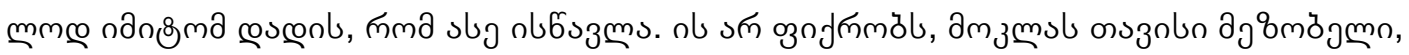

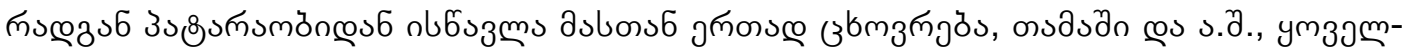

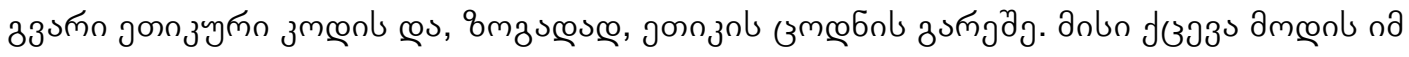

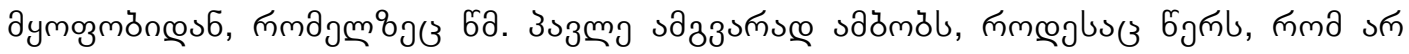

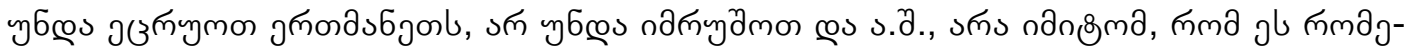

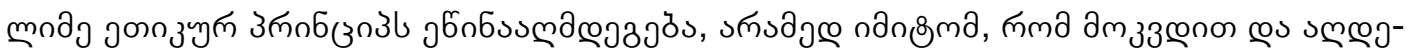

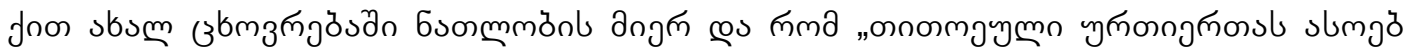

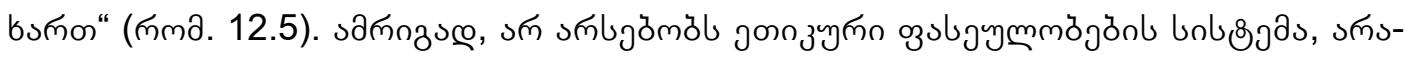

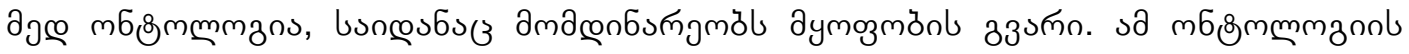

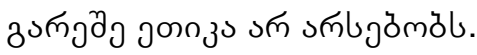

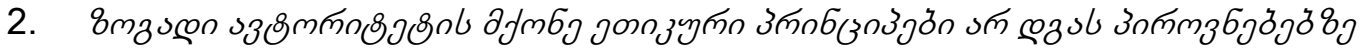

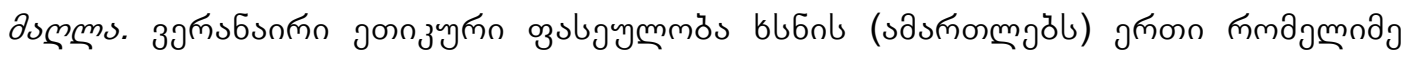

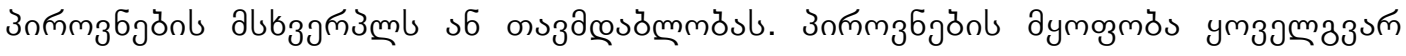

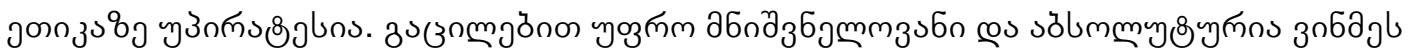

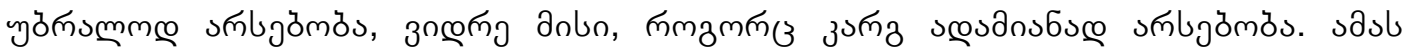

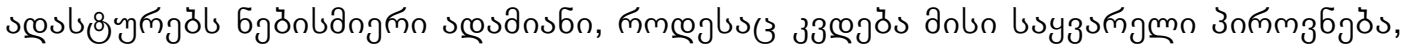

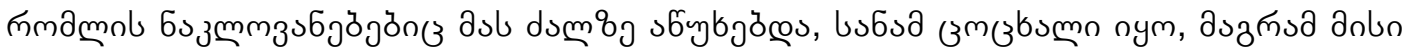

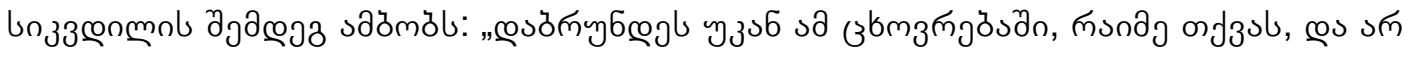

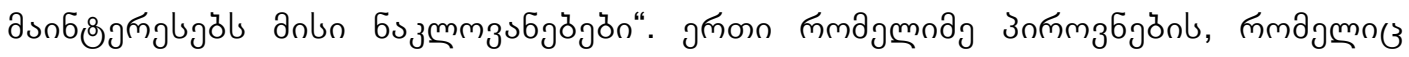
d sm

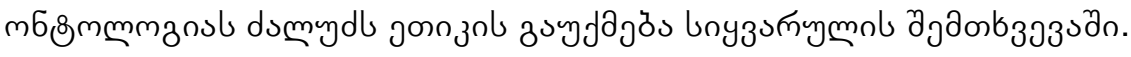

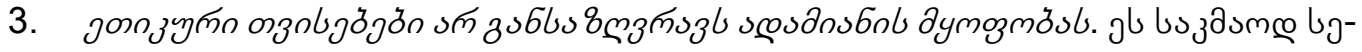

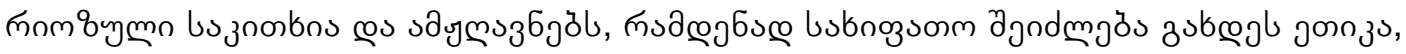

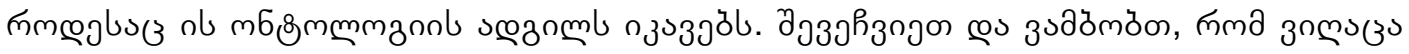

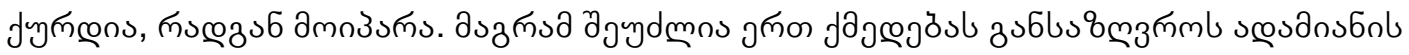




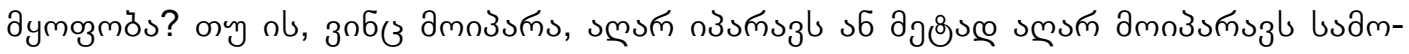

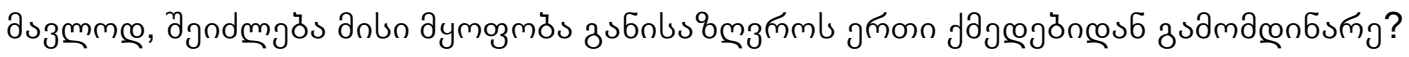

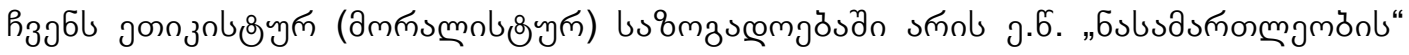

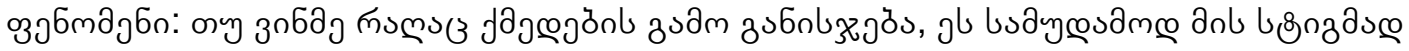

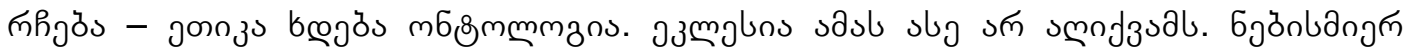

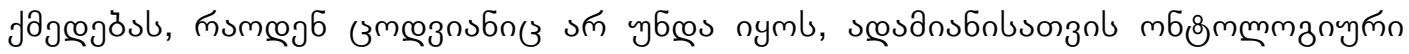

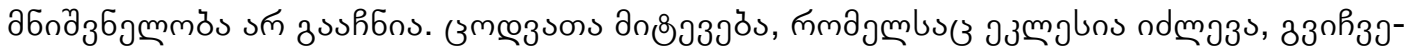

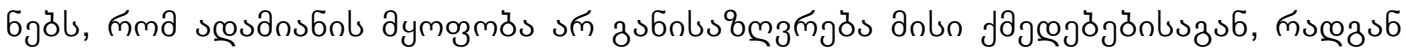

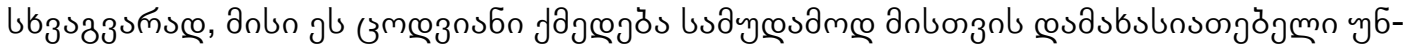

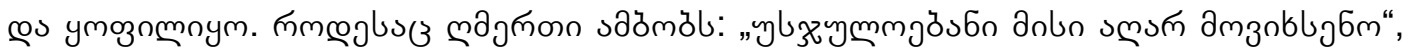

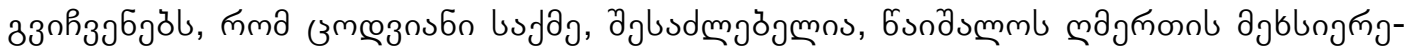

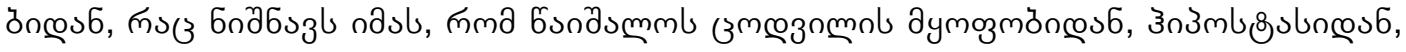

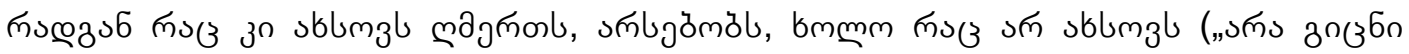

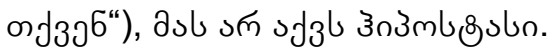

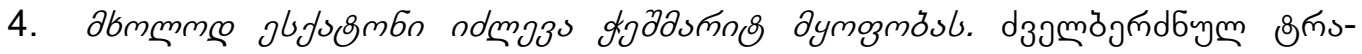

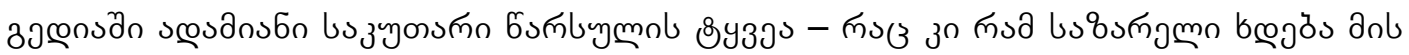

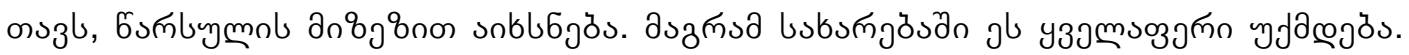

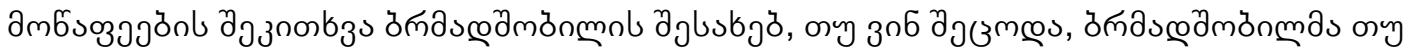

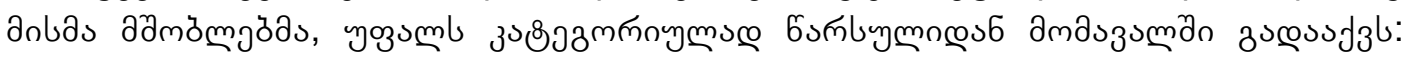

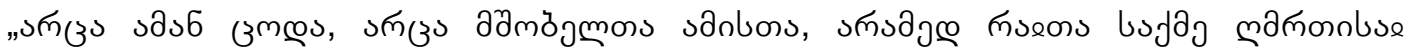

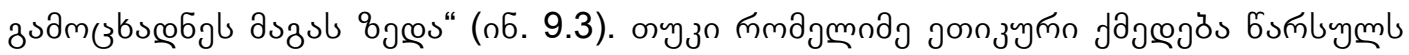

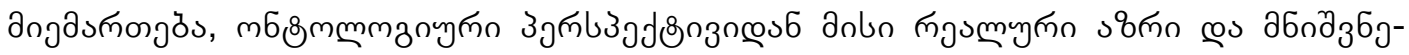

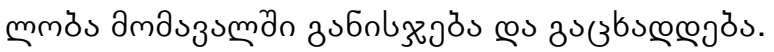

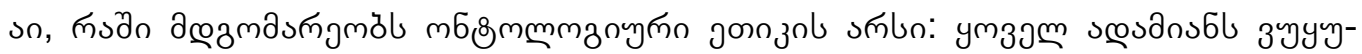

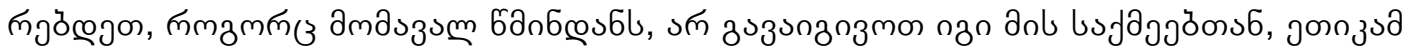

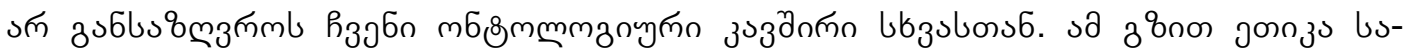

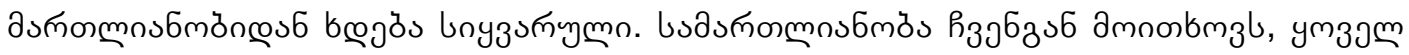

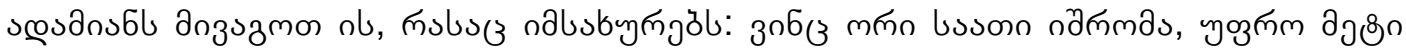

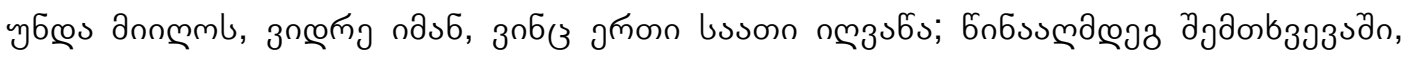

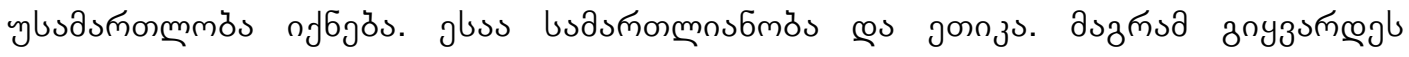
३мœзпмп sб

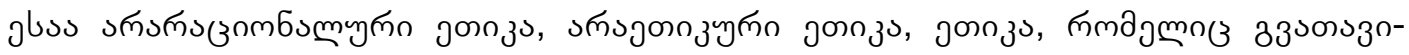

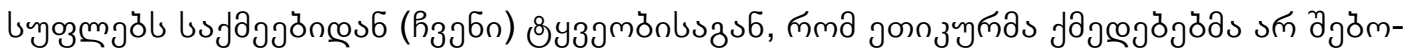

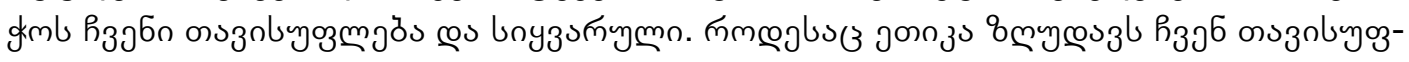

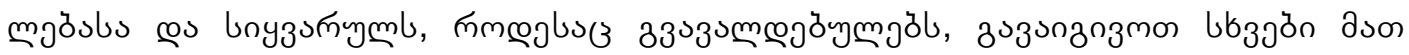

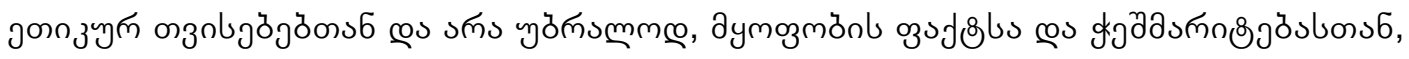

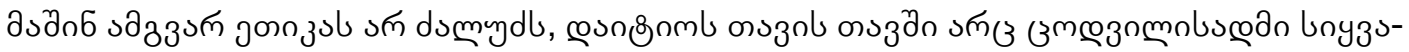

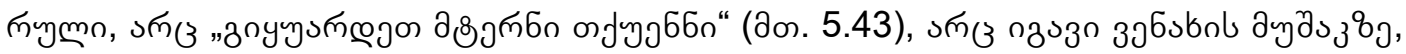

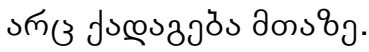




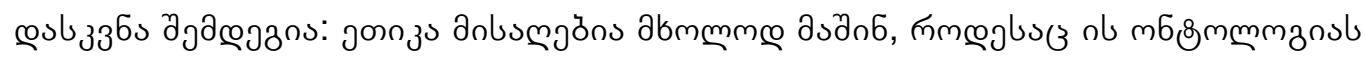

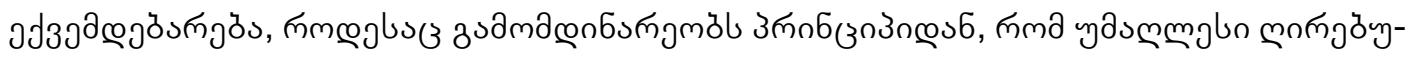

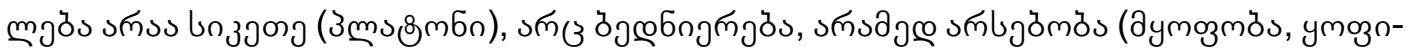

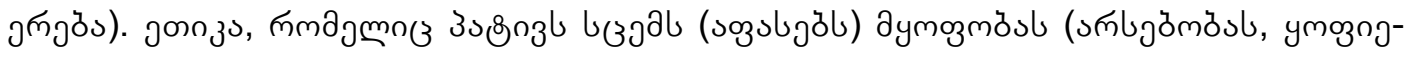

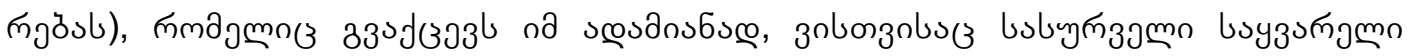

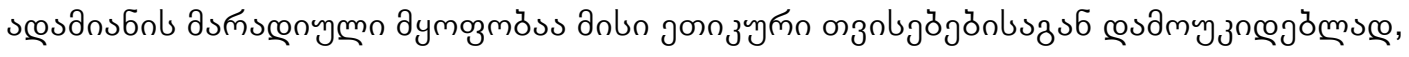

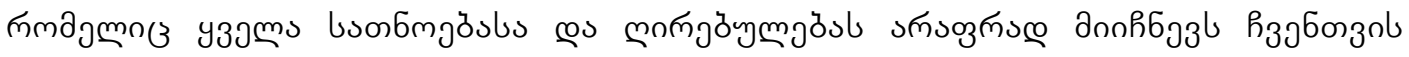

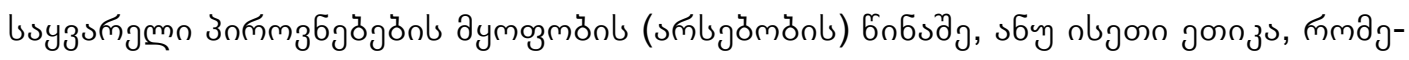

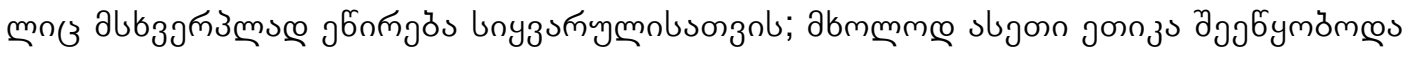

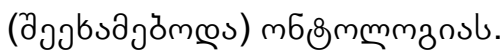

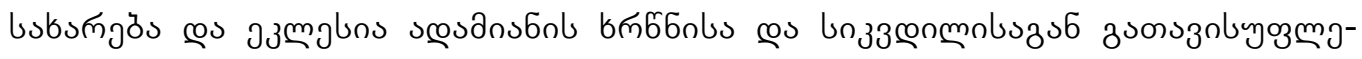

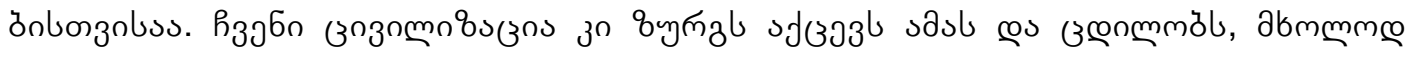
jon zn

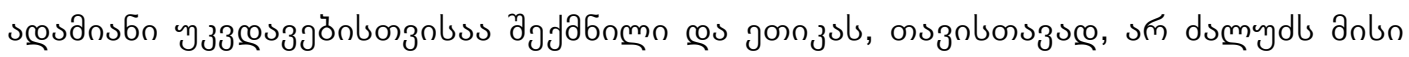

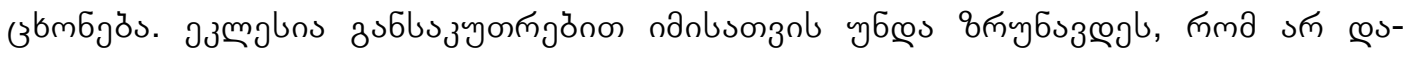

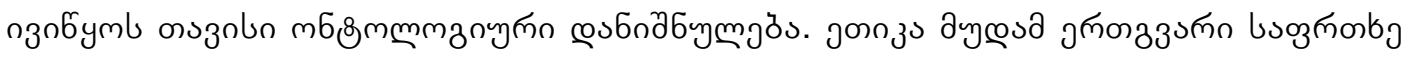

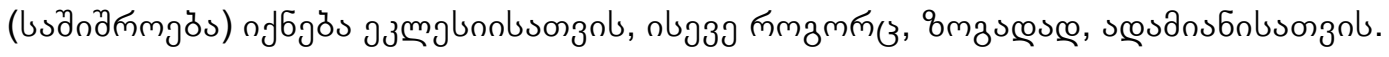

